\title{
Toward a systematic approach to opioid rotation
}

This article was published in the following Dove Press journal:

Journal of Pain Research

17 October 2014

Number of times this article has been viewed

\author{
Howard S Smith ${ }^{1, \dagger}$ \\ John F Peppin ${ }^{2,3}$ \\ 'Department of Anesthesiology, \\ Albany Medical College, Albany, \\ NY, USA; ${ }^{2}$ Global Scientific Affairs, \\ Mallinckrodt Pharmaceuticals, \\ St Louis, MO, USA; ${ }^{3}$ Center for \\ Bioethics, Pain Management and \\ Medicine, St Louis, MO, USA \\ ${ }^{\dagger}$ Author deceased May 18, 2013
}

\begin{abstract}
Patients requiring chronic opioid therapy may not respond to or tolerate the first opioid prescribed to them, necessitating rotation to another opioid. They may also require dose increases for a number of reasons, including worsening disease and increased pain. Dose escalation to restore analgesia using the primary opioid may lead to increased adverse events. In these patients, rotation to a different opioid at a lower-than-equivalent dose may be sufficient to maintain adequate tolerability and analgesia. In published trials and case series, opioid rotation is performed either using a predetermined substitute opioid with fixed conversion methods, or in a manner that appears to be no more systematic than trial and error. In clinical practice, opioid rotation must be performed with consideration of individual patient characteristics, comorbidities (eg, concurrent psychiatric, pulmonary, renal, or hepatic illness), and concurrent medications, using flexible dosing protocols that take into account incomplete opioid cross-tolerance. References cited in this review were identified via a search of PubMed covering all English language publications up to May 21, 2013 pertaining to opioid rotation, excluding narrative reviews, letters, and expert opinion. The search yielded a total of 129 articles, 92 of which were judged to provide relevant information and subsequently included in this review. Through a review of this literature and from the authors' empiric experience, this review provides practical information on performing opioid rotation in clinical practice.
\end{abstract}

Keywords: chronic pain, opioid rotation, opioid analgesics

\section{Introduction}

Pain affects millions of individuals in the United States and in fact is more prevalent than either heart disease or cancer. In 2010, back pain was reported by an estimated $28 \%$ of adults in the United States, neck pain by $15 \%$, and joint pain by $33 \%$. Some level of functional impairment was reported by approximately $50 \%$ of patients with back or joint pain. By comparison, heart disease and cancer were prevalent in $12 \%$ and $6 \%$ of US adults, respectively. ${ }^{1}$

Successful pain management rests on a full patient evaluation followed by implementation of a multidisciplinary and multimodal program of treatment that includes nonpharmacologic therapy (eg, diet, exercise, physical therapy, psychological therapy), nonopioid analgesics (eg, acetaminophen, nonsteroidal anti-inflammatory drugs), and adjuvants such as anticonvulsants and antidepressants. ${ }^{2}$ Opioid agents play an important role in the management of pain arising in a diverse set of clinical settings, including chronic pain of cancer origin, ${ }^{3}$ postoperative pain, ${ }^{4}$ and chronic pain of noncancer origin. ${ }^{5,6}$ However, their use must be selected on the basis of a careful balance of potential risks and benefits. ${ }^{7}$ Guidelines for the responsible use of opioids recommend
Center for Bioethics, Pain Management and Medicine, 8013 Presidio Court, University City, MO, 63130, USA

Tel +l 8592213154

Email johnpeppin@msn.com 
careful patient assessment to establish a legitimate diagnosis of pain and to identify factors that may predispose a patient to misuse a prescribed opioid. ${ }^{7-9}$ Once treatment commences, vigilant monitoring in all opioid-treated patients is essential to ensure compliance with prescribed therapies and to allow for prompt response to misuse..$^{7-9}$

In some patients, this balance may be optimized by careful dose adjustment or through implementation of other strategies, such as use of a bowel regimen to alleviate constipation or an antiemetic for nausea. Nonetheless, the selection of an appropriate opioid dose and treatment regimen that provides improved function and quality of life with acceptable tolerability is complicated by several factors that may not be amenable to these corrective measures. These factors include differences between opioids (eg, receptor binding, metabolism), efficacy and tolerability differences between patient subgroups (sex, ethnicity, age), interindividual variability of response, and the specific opioid used; patient factors of importance include comorbidities, concurrent medications, personal history (eg, substance abuse, psychiatric illness), and genetic makeup. ${ }^{10-12}$ Attempting to downplay these complexities does not improve patient care and, at worst, may contribute to some of the serious psychosocial costs associated with available analgesics. In some cases, the aggregate of factors limiting response to a given opioid will best be addressed by rotation to a substitute opioid that better aligns with the individual patient's needs.

Guidelines for the safe and effective use of opioids have been proposed by several professional organizations (eg, American Pain Society, American Academy of Pain Medicine) and expert panels..$^{7,8,13-15}$ However, the clinical practice of opioid rotation is predominantly guided by arbitrary routine, clinician preference, or formulary limitations. Expert opinion and consensus statements concur that there is generally a lack of high-quality evidence to support the practice of opioid rotation or to guide the selection of a new opioid when dose adjustments with the present opioid regimen cannot resolve increasing adverse effects or waning efficacy. ${ }^{13,14,16-18}$

The objectives of this review are to provide steps toward a systematic approach to opioid rotation with which clinicians can choose the new opioid based on a thoughtful assessment of the likely causes of the adverse effects or poor efficacy with the present therapy. This discussion is limited to opioids appropriate for long-term therapy for chronic pain.

\section{Search methodology}

References cited in this review were identified via a search of PubMed covering all English language publications up to May 21, 2013; the search included clinical trials, guidelines, meta-analyses, systematic reviews, and case reports but excluded narrative reviews, letters, and expert opinion. Using the search string "(opioid OR buprenorphine OR codeine OR fentanyl OR hydrocodone OR hydromorphone OR methadone OR meperidine OR morphine OR oxycodone OR oxymorphone) AND (switching OR rotation OR conversion) AND chronic"; the search yielded a total of 129 articles, 92 of which were judged to provide relevant information and were included in this review. Of these, 50 were clinical trials or case reports, and the remaining 42 pertained to the scientific rationale for various aspects of opioid rotation. Treatment guidelines and references identified via this strategy were reviewed for additional articles of interest.

\section{Opioid rotation: published literature}

Expert opinion, through a review of this literature, suggests that nearly all opioids may be effective for the relief of pain and that there is insufficient clinical evidence to support the selection of one opioid over another for the initiation of treatment or to systematically guide the selection of a new opioid when the need for opioid rotation arises. ${ }^{18-20}$ Such guidance is necessary because specific patient subgroups may be more or less susceptible to analgesic or specific side effects of a given opioid, whereas individuals within those subgroups also show variability of clinical response and ability to tolerate specific opioids.

Factors contributing to this variability include demographic differences that affect susceptibility to analgesic and adverse effects, ${ }^{10,21,22}$ the presence of comorbidities, ${ }^{23}$ and genetic factors that influence opioid metabolism ${ }^{24}$ and analgesic response. ${ }^{11}$ Of these, genetic factors are least clearly understood and are not routinely tested before initiating opioid therapy. To some extent, successful rotation is a process of trial and error. However, as discussed below, this process can be conducted more methodically to maximize the likelihood of a good clinical outcome with each trial.

Reasons for opioid rotation mentioned in the literature include the following: intolerable adverse events during dose titration, lack of analgesic efficacy despite optimal dose titration, occurrence of problematic drug-drug interactions (DDIs), change in clinical status (eg, risk for drug abuse), and practical issues (eg, cost, availability of drug). ${ }^{14}$ Clinical trials and case series examined for this article are summarized in Table 1.

We cited all of the clinical trials that described a rotation, and there was no selection process. All of the clinical trials evaluating opioid rotation identified in our search have inclusion and exclusion criteria for trial participants that may result in a rarefied study population. The goal of trial design was 
Table I Characteristics of clinical trials/case series describing opioid rotation

\begin{tabular}{|c|c|c|c|c|}
\hline Study & Design & Participants & Rotation method & Outcomes \\
\hline $\begin{array}{l}\text { Hallett and } \\
\text { Chalkiadis }^{128}\end{array}$ & Case report & $\begin{array}{l}\text { Postsurgical pediatric patient, } \\
\text { on opioids uncontrolled }\end{array}$ & $\begin{array}{l}\text { Rotation to hydromorphone } \\
\text { and ketamine commenced }\end{array}$ & $\begin{array}{l}\text { Pain score } 24 \mathrm{~h} \text { after opioid } \\
\text { rotation }\end{array}$ \\
\hline $\begin{array}{l}\text { McDonnell } \\
\text { et } \mathrm{al}^{42}\end{array}$ & $\begin{array}{l}\text { Randomized } \\
\text { clinical trial }\end{array}$ & $\begin{array}{l}44 \text { pediatric chronic pain } \\
\text { of noncancer origin patients } \\
\text { on PCA morphine }\end{array}$ & $\begin{array}{l}\text { Rotation to PCA hydromorphone } \\
\text { in seven patients with pain not } \\
\text { controlled with PCA morphine }\end{array}$ & $\begin{array}{l}\text { PCA ratio of patient demands } \\
\text { to pump deliveries }\end{array}$ \\
\hline $\begin{array}{l}\text { Oldenmenger } \\
\text { et } \mathrm{al}^{43}\end{array}$ & $\begin{array}{l}\text { Prospective } \\
\text { observational } \\
\text { study }\end{array}$ & $\begin{array}{l}104 \text { chronic pain of cancer } \\
\text { origin patients uncontrolled } \\
\text { with existing opioid analgesic }\end{array}$ & $\begin{array}{l}\text { Rotation to IV hydromorphone } \\
\text { due to poor pain control }(n=61) \text {, } \\
\text { intolerable AEs }(n=43)\end{array}$ & $\begin{array}{l}\text { Pain control (pain intensity; } \\
\text { duration of failure-free } \\
\text { treatment) }\end{array}$ \\
\hline $\begin{array}{l}\text { Ostgathe } \\
\text { et } \mathrm{al}^{44}\end{array}$ & $\begin{array}{l}\text { Retrospective } \\
\text { chart review }\end{array}$ & $\begin{array}{l}52 \text { inpatient palliative care } \\
\text { patients }\end{array}$ & $\begin{array}{l}\text { Titrate oral levo-methadone, } \\
\text { maintain single dose after } 72 \mathrm{~h} \\
\text { titration, increase dosing interval to } \\
\text { q8h (plus PRN q3h) }\end{array}$ & $\begin{array}{l}\text { Pain intensity (NRS); } \\
\text { amount of dosing after } \\
72 \text { h number maintained } \\
\text { single dose until } \\
\text { AEs }\end{array}$ \\
\hline Sato et al ${ }^{129}$ & Case series & $\begin{array}{l}\text { Two patients undergoing } \\
\text { pain management in the } \\
\text { home-care setting }\end{array}$ & $\begin{array}{l}\text { Rotation from fentanyl to continuous IV } \\
\text { morphine at less than the equivalent } \\
\text { dose based on conversion table }\end{array}$ & $\begin{array}{l}\text { Risk of delay in detection of } \\
\text { adverse reactions to opioid } \\
\text { overdose }\end{array}$ \\
\hline $\begin{array}{l}\text { Webster } \\
\text { and Fine }{ }^{130}\end{array}$ & Case report & $\begin{array}{l}\text { Patient undergoing pain } \\
\text { management using a new } \\
\text { paradigm }\end{array}$ & $\begin{array}{l}\text { Rotation based on a slow decrease in the } \\
\text { dose of previous oxycodone ER and slow } \\
\text { titration of the dose of hydromorphone } \\
\text { ER with IR opioid to control BTP }\end{array}$ & $\begin{array}{l}\text { Pain control } \\
\text { AEs }\end{array}$ \\
\hline $\begin{array}{l}\text { Weiner } \\
\text { et } \mathrm{al}^{\mid 31}\end{array}$ & Case report & $\begin{array}{l}\text { Patient with central pain } \\
\text { syndrome uncontrolled by } \\
\text { PO morphine and hydrocodone } \\
\text { with acetaminophen }\end{array}$ & $\begin{array}{l}\text { Step I: unsuccessful rotation from } \\
\text { morphine to transdermal fentanyl } \\
\text { Step } 2 \text { : successful rotation to transdermal } \\
\text { buprenorphine } 60 \mu \mathrm{g} / \mathrm{h} \text { q7d }\end{array}$ & $\begin{array}{l}\text { Self-reported pain control } \\
\text { (VAS) } \\
\text { Performance status }\end{array}$ \\
\hline $\begin{array}{l}\text { Hanaoka } \\
\text { et } \text { al }^{48}\end{array}$ & $\begin{array}{l}\text { Prospective } \\
\text { observational } \\
\text { study }\end{array}$ & $\begin{array}{l}66 \text { chronic pain of cancer origin } \\
\text { patients with uncontrolled } \\
\text { moderate to severe pain }\end{array}$ & $\begin{array}{l}\text { Rotation from existing opioid to fentanyl } \\
\text { patch (I-day formulation) based on dose } \\
\text { level of preceding opioid analgesic }\end{array}$ & $\begin{array}{l}\text { Pain control } \\
\text { AEs }\end{array}$ \\
\hline $\begin{array}{l}\text { Kawano } \\
\text { et } \mathrm{al}^{49}\end{array}$ & $\begin{array}{l}\text { Prospective } \\
\text { observational } \\
\text { study }\end{array}$ & $\begin{array}{l}45 \text { chronic pain of cancer } \\
\text { origin patients }\end{array}$ & $\begin{array}{l}\text { Rotation from morphine IV to transdermal } \\
\text { fentanyl patch }\end{array}$ & $\begin{array}{l}\text { Equivalent doses and } \\
\text { conversion ratios for daily } \\
\text { delivered dose of morphine } \\
\text { injection and fentanyl patch }\end{array}$ \\
\hline $\begin{array}{l}\text { Korkmazsky } \\
\text { et } \mathrm{al}^{4 !}\end{array}$ & $\begin{array}{l}\text { Prospective } \\
\text { observational } \\
\text { study }\end{array}$ & $\begin{array}{l}\text { Patients with chronic pain } \\
\text { of noncancer origin receiving } \\
\text { morphine or oxycodone } \\
\text { for } \geq 3 \text { months }\end{array}$ & $\begin{array}{l}\text { Rotation to oral oxymorphone ER with } \\
\text { IV-PCA oxymorphone for } 24 \text { h PRN } \\
\text { and oxymorphone IR based on total } \\
\text { 24-h IV-PCA oxymorphone use }\end{array}$ & $\begin{array}{l}\text { AEs } \\
\text { Patient PGIC and BPI } \\
\text { Treatment satisfaction } \\
\text { Change in oxymorphone dose }\end{array}$ \\
\hline Gatti et $\mathrm{al}^{40}$ & $\begin{array}{l}\text { Multicenter, } \\
\text { open-label } \\
\text { prospective } \\
\text { trial }\end{array}$ & $\begin{array}{l}326 \text { patients with chronic pain of } \\
\text { cancer or noncancer origin not } \\
\text { controlled by SR opioid alone: } \\
\text { Morphine }<320 \mathrm{mg} \\
\text { Oxycodone }<120 \mathrm{mg} \\
\text { Hydromorphone }<64 \mathrm{mg} \\
\text { Fentanyl }<125 \mu \mathrm{g} \\
\text { Buprenorphine }<140 \mathrm{mg} \\
\text { or in combination with analgesics }\end{array}$ & $\begin{array}{l}\text { Step I: Rotation to oral IR morphine } \\
5 \text { or } 10 \mathrm{mg} \text { q } 4 \text { h to reduce pain score } \\
\text { to } \leq 50 \% \text { of baseline; } \\
\text { Step } 2 \text { : rotation from IR morphine } \\
\text { to a different SR opioid } \\
\text { (no guidelines for opioid choice) }\end{array}$ & $\begin{array}{l}\text { Pain intensity (NRS score) } \\
\text { Daily episodes of BTP } \\
\text { (BPI scale) } \\
\text { AEs } \\
\text { Treatment compliance }\end{array}$ \\
\hline $\begin{array}{l}\text { Parsons } \\
\text { et } \mathrm{al}^{46}\end{array}$ & $\begin{array}{l}\text { Retrospective } \\
\text { chart review }\end{array}$ & $\begin{array}{l}\text { I } 89 \text { chronic pain of cancer } \\
\text { origin patients }\end{array}$ & $\begin{array}{l}\text { Rotation to methadone }(n=89) \\
\text { in an outpatient setting }\end{array}$ & $\begin{array}{l}\text { Methadone rotation } \\
\text { Success rate } \\
\text { Reasons for opioid rotation } \\
\text { Mean daily methadone dose } \\
\text { Demographic and clinical } \\
\text { characteristics, pain scores, } \\
\text { and opioid AEs }\end{array}$ \\
\hline $\begin{array}{l}\text { Benítez- } \\
\text { Rosario } \\
\text { et } \mathrm{al}^{25}\end{array}$ & $\begin{array}{l}\text { Retrospective } \\
\text { analysis }\end{array}$ & $\begin{array}{l}54 \text { severe pain of cancer } \\
\text { origin patients uncontrolled } \\
\text { by morphine }\end{array}$ & $\begin{array}{l}\text { Opioid rotation: } \\
\text { Methadone initial dose calculated using } \\
\text { MMEDR of 5:I } \\
\text { Dose calculated at a ratio of } 10: 1 \text { in patients } \\
\text { receiving }>600 \mathrm{mg} / \mathrm{d} \text { morphine who were } \\
\text { anxious, depressed, or delirious and had a } \\
\text { history of rapid increase in morphine dose } \\
\text { or low morphine clearance }\end{array}$ & $\begin{array}{l}\text { MMEDR at day } 10 \text { with } \\
\text { explanatory factors in } \\
\text { multiple linear regression } \\
\text { model }\end{array}$ \\
\hline
\end{tabular}


Table I (Continued)

\begin{tabular}{|c|c|c|c|c|}
\hline Study & Design & Participants & Rotation method & Outcomes \\
\hline Leppert $^{50}$ & $\begin{array}{l}\text { Prospective } \\
\text { observational } \\
\text { study }\end{array}$ & $\begin{array}{l}21 \text { chronic pain of cancer } \\
\text { origin patients: morphine } \\
(n=1) \text {, transdermal fentanyl } \\
(n=4) \text {, morphine, ketamine and } \\
\text { transdermal fentanyl }(n=I) \text {, } \\
\text { tramadol }(n=I) \text {, pethidine }(n=I) \text {, } \\
\text { or morphine with ketamine }(n=3)\end{array}$ & $\begin{array}{l}\text { Rotation from previous opioid using } \\
\text { stop-start approach to oral methadone; } \\
\text { equivalent DDOM to DDOMET were } \\
\text { 4:I (DDOM to I00 mg), 6:I ( } 10 \mathrm{I}-300 \mathrm{mg}) \text {, } \\
\text { I2:I (>I,000 mg); with BTP treated } \\
\text { with methadone } \mathrm{S}^{32} \text { and other agents }\end{array}$ & $\begin{array}{l}\text { Methadone analgesia } \\
\text { AEs } \\
\text { Effectiveness of DDOM to } \\
\text { DDOMET dose calculation } \\
\text { method }\end{array}$ \\
\hline $\begin{array}{l}\text { Matsuyama } \\
\text { et } \mathrm{al}^{133}\end{array}$ & Case report & $\begin{array}{l}\text { Chronic pain of cancer origin } \\
\text { patient uncontrolled with } \\
\text { oxycodone ER }\end{array}$ & $\begin{array}{l}\text { Rotation to matrix-type transdermal } \\
\text { fentanyl }\end{array}$ & $\begin{array}{l}\text { Pain relief } \\
\text { Relief of severe constipation }\end{array}$ \\
\hline $\begin{array}{l}\text { Cheema } \\
\text { et }\left.a\right|^{38}\end{array}$ & $\begin{array}{l}\text { Prospective } \\
\text { observational } \\
\text { study }\end{array}$ & $\begin{array}{l}49 \text { chronic pain of cancer } \\
\text { origin patients }\end{array}$ & $\begin{array}{l}\text { Rotation from oxycodone to morphine } \\
(\mathrm{n}=23,47 \%) \text { followed by a second }(12 \%) \text {, } \\
\text { third }(3 \%) \text {, and fourth }(2 \%) \text { opioid } \\
\text { rotation }\end{array}$ & $\begin{array}{l}\text { Frequency of opioid rotation } \\
\text { Indications for opioid } \\
\text { rotation: inadequate analgesia, } \\
\text { AEs, cost, organ failure, NP, } \\
\text { route and dosing convenience }\end{array}$ \\
\hline Davies et $\mathrm{a}^{51}$ & $\begin{array}{l}\text { Retrospective } \\
\text { analysis }\end{array}$ & $\begin{array}{l}\text { I7 chronic pain of cancer origin } \\
\text { pediatric patients with uncontrolled } \\
\text { pain from primary opioid }\end{array}$ & $\begin{array}{l}\text { Rotation to methadone from primary } \\
\text { opioid based on morphine equivalent } \\
\text { dose (range, } 1: 2 \text { to } 60: 1 \text { ) }\end{array}$ & $\begin{array}{l}\text { AEs } \\
\text { Improvement in analgesia }\end{array}$ \\
\hline Likar et al ${ }^{134}$ & Case series & $\begin{array}{l}\text { Four chronic pain of noncancer } \\
\text { origin patients with uncontrolled } \\
\text { pain with existing opioids }\end{array}$ & Rotation to transdermal buprenorphine & $\begin{array}{l}\text { Opioid conversion ratio } \\
\text { Pain relief }\end{array}$ \\
\hline $\begin{array}{l}\text { Narabayashi } \\
\text { et al }{ }^{30}\end{array}$ & $\begin{array}{l}\text { Multicenter, } \\
\text { open-label } \\
\text { dose-titration } \\
\text { study }\end{array}$ & $\begin{array}{l}25 \text { cancer patients with } \\
\text { inadequate pain control } \\
\text { or intolerable adverse events } \\
\text { on morphine }\end{array}$ & $\begin{array}{l}\text { Rotation to oxycodone CR using } \\
\text { a 3:2 oxycodone:morphine ratio }\end{array}$ & $\begin{array}{l}\text { Pain on a } 4 \text {-point categorical } \\
\text { rating scale: } 0=\text { no pain, } \\
3=\text { severe pain } \\
\text { Oxycodone dose stability } \\
\text { AEs }\end{array}$ \\
\hline $\begin{array}{l}\text { Okon and } \\
\text { George }\end{array}$ & Case report & $\begin{array}{l}\text { Pain of cancer origin patient } \\
\text { with uncontrolled pain with } \\
\text { increasing doses of opioids }\end{array}$ & $\begin{array}{l}\text { Rotation from IV morphine to } \\
\text { transdermal fentanyl with dose } \\
\text { increase to } 200 \mu \mathrm{g} / \mathrm{h} \text { for } \\
\text { persistent severe pain }\end{array}$ & $\begin{array}{l}\text { Pain control } \\
\text { Resolution of symptoms }\end{array}$ \\
\hline Peng et $\mathrm{a}^{39}$ & $\begin{array}{l}\text { Retrospective } \\
\text { chart review }\end{array}$ & $\begin{array}{l}\text { I00 chronic pain of noncancer } \\
\text { origin patients }\end{array}$ & $\begin{array}{l}\text { Rotation to methadone from previous } \\
\text { opioid analgesic based on morphine- } \\
\text { equivalent dose before methadone } \\
\text { therapy }\end{array}$ & $\begin{array}{l}\text { Methadone stabilized dose } \\
\text { Consistency of conversion } \\
\text { ratio } \\
\text { Duration of therapy } \\
\text { Pain intensity NVRS } \\
\text { Use of concomitant agents } \\
\text { AEs }\end{array}$ \\
\hline $\begin{array}{l}\text { Vorobeychik } \\
\text { et al al }{ }^{136}\end{array}$ & Case report & $\begin{array}{l}\text { Chronic pain of cancer origin } \\
\text { patient with pain uncontrolled } \\
\text { by escalating doses of oxycodone, } \\
\text { morphine, and hydromorphone }\end{array}$ & $\begin{array}{l}\text { Rotation to methadone following } \\
40 \%-50 \% \text { reduction in dose } \\
\text { of hydromorphone }\end{array}$ & $\begin{array}{l}\text { Pain intensity (VAS) } \\
\text { Mental status }\end{array}$ \\
\hline Walker et $\mathrm{al}^{47}$ & $\begin{array}{l}\text { Retrospective } \\
\text { chart review }\end{array}$ & $\begin{array}{l}39 \text { chronic pain of cancer } \\
\text { origin patients with pain poorly } \\
\text { controlled by existing opioid }\end{array}$ & $\begin{array}{l}\text { Rotation to oral and IV methadone } \\
\text { based on oral MEDD of previous } \\
\text { opioid }\end{array}$ & $\begin{array}{l}\text { Dose ratio for oral and IV } \\
\text { methadone to oral MEDD } \\
\text { Latency of achieving stabilized } \\
\text { dose }\end{array}$ \\
\hline $\begin{array}{l}\text { Akiyama } \\
\text { et } \mathrm{al}^{137}\end{array}$ & Case series & $\begin{array}{l}22 \text { severe chronic pain } \\
\text { of cancer origin patients }\end{array}$ & $\begin{array}{l}\text { Rotation from morphine } \\
\text { to transdermal fentanyl patch }\end{array}$ & $\begin{array}{l}\text { Transition to home-care } \\
\text { setting } \\
\text { Control of pain, analgesic } \\
\text { effect, and AEs }\end{array}$ \\
\hline Braiteh et al ${ }^{52}$ & $\begin{array}{l}\text { Retrospective } \\
\text { chart review }\end{array}$ & $\begin{array}{l}61 \text { chronic pain of cancer } \\
\text { origin patients }\end{array}$ & $\begin{array}{l}\text { Neuroleptics ( } n=33,54 \% \text { ); opioid } \\
\text { rotation (not specified; } n=30,49 \% \text { ) }\end{array}$ & $\begin{array}{l}\text { Reasons for mobile team } \\
\text { consultation: pain }(n=47,77 \%) \\
\text { and delirium ( } n=10,16 \%) \\
\text { Improvement in pain at } 24 \\
\text { and } 72 \mathrm{~h}\end{array}$ \\
\hline
\end{tabular}

(Continued) 
Table I (Continued)

\begin{tabular}{|c|c|c|c|c|}
\hline Study & Design & Participants & Rotation method & Outcomes \\
\hline $\begin{array}{l}\text { Clemens } \\
\text { and Klaschik }{ }^{53}\end{array}$ & $\begin{array}{l}\text { Retrospective } \\
\text { analysis }\end{array}$ & $\begin{array}{l}8 \mathrm{I} \text { chronic pain of cancer } \\
\text { origin patients pretreated } \\
\text { with transdermal fentanyl }\end{array}$ & $\begin{array}{l}\text { Rotation from transdermal fentanyl } \\
\text { to oral morphine }(n=33) \text { or oral } \\
\text { hydromorphone }(n=44)\end{array}$ & $\begin{array}{l}\text { Decrease in pain score } \\
\text { (NRS at rest/exertion); } \\
\text { tolerability of oral morphine } \\
\text { or hydromorphone }\end{array}$ \\
\hline Freye et $\mathrm{a}^{37}$ & $\begin{array}{l}\text { Prospective } \\
\text { observational } \\
\text { study }\end{array}$ & $\begin{array}{l}42 \text { chronic pain of cancer and } \\
\text { noncancer origin patients with } \\
\text { pain uncontrolled with high-dose } \\
\text { morphine }(120->240 \mathrm{mg} / \mathrm{d})\end{array}$ & $\begin{array}{l}\text { Rotation from morphine to } \\
\text { buprenorphine }(\geq 52.5 \mathrm{mg} / \mathrm{h})\end{array}$ & $\begin{array}{l}\text { Pain relief } \\
\text { Patient satisfaction and QOL } \\
\text { Severity of adverse drug } \\
\text { reactions }\end{array}$ \\
\hline Hale et $\mathrm{al}^{27}$ & $\begin{array}{l}\text { Double-blind, } \\
\text { placebo- } \\
\text { controlled } \\
\text { study }\end{array}$ & $\begin{array}{l}250 \text { chronic low back pain } \\
\text { patients with pain uncontrolled } \\
\text { by hydrocodone, oxycodone, } \\
\text { morphine, methadone, fentanyl, } \\
\text { codeine, }{ }^{\text {a }} \text { or propoxyphene }\end{array}$ & $\begin{array}{l}\text { Conversion to oxymorphone ER based } \\
\text { on calculated equianalgesic doses; } \\
\text { titration was based on response } \\
\text { every } 3-7 \mathrm{~d}\end{array}$ & $\begin{array}{l}\text { Successful titration } \\
\text { VAS Pain Intensity } \\
\text { AEs }\end{array}$ \\
\hline Riley et a $\left.\right|^{12}$ & $\begin{array}{l}\text { Prospective, } \\
\text { observational, } \\
\text { controlled } \\
\text { study }\end{array}$ & $\begin{array}{l}\text { I } 86 \text { cancer pain patients treated } \\
\text { with morphine; non-responders } \\
\text { rotated to oxycodone CR, } \\
\text { fentanyl, or methadone }\end{array}$ & Not specified & $\begin{array}{l}\text { Subjective assessment of pain } \\
\text { control } \\
\text { AEs }\end{array}$ \\
\hline Wirz et $a^{56}$ & $\begin{array}{l}\text { Prospective, } \\
\text { observational, } \\
\text { study }\end{array}$ & $\begin{array}{l}50 \text { chronic pain of cancer origin } \\
\text { patients in an outpatient setting }\end{array}$ & $\begin{array}{l}\text { Rotation from oral morphine, } \\
\text { transdermal fentanyl, tramadol, } \\
\text { oxycodone, and sublingual buprenorphine } \\
\text { to oral hydromorphone ER } \\
\text { (MED, I08.9-137.6 mg/d) without } \\
\text { modifying concomitant analgesics }\end{array}$ & $\begin{array}{l}\text { Pain intensity (NRS) } \\
\text { Gastrointestinal symptoms } \\
\text { Relief of insomnia }\end{array}$ \\
\hline Morita et $\mathrm{al}^{29}$ & $\begin{array}{l}\text { Retrospective } \\
\text { analysis }\end{array}$ & $\begin{array}{l}20 \text { chronic pain of cancer origin } \\
\text { patients with morphine-induced } \\
\text { delirium }\end{array}$ & $\begin{array}{l}\text { Morphine switched to equivalent fentanyl } \\
\text { (transdermal or parenteral) } \\
\text { using a conversion ratio } \\
\text { (morphine } 10 \mathrm{mg} \text { = fentanyl } 159 \mathrm{mg} \text { ) }\end{array}$ & $\begin{array}{l}\text { Severity of delirium (MDAS) } \\
\text { Pain (STAS) } \\
\text { Performance status }\end{array}$ \\
\hline Moryl et al ${ }^{138}$ & $\begin{array}{l}\text { Retrospective } \\
\text { analysis }\end{array}$ & $\begin{array}{l}20 \text { opioid-refractory chronic } \\
\text { pain of cancer origin patients } \\
\text { with uncontrolled pain and } \\
\text { terminal delirium }\end{array}$ & $\begin{array}{l}\text { Rotation to equianalgesic dose of } \\
\text { methadone based on previous morphine- } \\
\text { equivalent dose ( } n=7) ; 2 \text { patients } \\
\text { restarted on morphine IV; I patient } \\
\text { restarted on acetaminophen + oxycodone }\end{array}$ & $\begin{array}{l}\text { Pain control (NRS) } \\
\text { Severity of delirium (MDAS) } \\
\text { Alertness and cognitive status }\end{array}$ \\
\hline $\begin{array}{l}\text { Muller-Busch } \\
\text { et } \text { al }^{139}\end{array}$ & $\begin{array}{l}\text { Multicenter, } \\
\text { prospective } \\
\text { observational } \\
\text { study }\end{array}$ & $\begin{array}{l}412 \text { palliative care patients } \\
\text { receiving opioids }\end{array}$ & $\begin{array}{l}\text { Rotation from oral to parenteral } \\
\text { morphine }(n=106) \text { or to other } \\
\text { long-acting opioids }(n=49)\end{array}$ & $\begin{array}{l}\text { AEs and efficacy } \\
\text { Correlation between baseline } \\
\text { opioid use and rotation } \\
\text { frequency }\end{array}$ \\
\hline $\begin{array}{l}\text { Shinjo } \\
\text { and Okada }{ }^{140}\end{array}$ & Case report & $\begin{array}{l}\text { Chronic pain of cancer origin } \\
\text { patient with pain uncontrolled } \\
\text { by escalating doses } \\
\text { of transdermal fentanyl }\end{array}$ & $\begin{array}{l}\text { Rotation to transdermal fentanyl } \\
(150 \mu \mathrm{g} / \mathrm{h}) \text { in combination with oral } \\
\text { morphine SR }(360 \mathrm{mg} / \mathrm{d})\end{array}$ & Pain control \\
\hline $\begin{array}{l}\text { Zimmermann } \\
\text { et } \mathrm{al}^{141}\end{array}$ & Case series & $\begin{array}{l}\text { Two chronic pain of cancer origin } \\
\text { patients with pain uncontrolled } \\
\text { by escalating doses of parenteral } \\
\text { hydromorphone }\end{array}$ & $\begin{array}{l}\text { Rotation to a smaller than predicted } \\
\text { dose of oral methadone }\end{array}$ & $\begin{array}{l}\text { Pain control } \\
\text { AEs }\end{array}$ \\
\hline $\begin{array}{l}\text { Benítez- } \\
\text { Rosario } \\
\text { et } \mathrm{al}^{45}\end{array}$ & $\begin{array}{l}\text { Prospective } \\
\text { observational } \\
\text { study }\end{array}$ & $\begin{array}{l}\text { I7 cancer patients receiving } \\
\text { transdermal fentanyl }\end{array}$ & $\begin{array}{l}\text { Rotation to oral methadone: } \\
\text { Step I: transdermal fentanyl: } \\
\text { oral morphine }(I: 100) \\
\text { Step 2: oral morphine: } \\
\text { oral methadone }(5: I \text { or } 10: I)\end{array}$ & $\begin{array}{l}\text { Correlation between } \\
\text { previous fentanyl dose } \\
\text { and final methadone dose; } \\
\text { change in pain intensity after } \\
\text { rotation; use of daily rescue } \\
\text { doses }\end{array}$ \\
\hline Drake et $\mathrm{al}^{36}$ & $\begin{array}{l}\text { Retrospective } \\
\text { analysis }\end{array}$ & $\begin{array}{l}22 \text { chronic pain of cancer } \\
\text { origin children with pain } \\
\text { uncontrolled with morphine }\end{array}$ & $\begin{array}{l}\text { Rotations from morphine to fentanyl } \\
\text { favored in } 20 \text { of } 30(67 \%) \text { rotations } \\
\text { Rotation from fentanyl } \\
\text { to hydromorphone favored } \\
\text { in } 6 \text { of } 30(20 \%) \text { rotations }\end{array}$ & $\begin{array}{l}\text { Pain intensity } \\
\text { AEs } \\
\text { MED after rotation }\end{array}$ \\
\hline
\end{tabular}

(Continued) 
Table I (Continued)

\begin{tabular}{|c|c|c|c|c|}
\hline Study & Design & Participants & Rotation method & Outcomes \\
\hline Kato et a ${ }^{54}$ & $\begin{array}{l}\text { Prospective } \\
\text { observational } \\
\text { study }\end{array}$ & $\begin{array}{l}\text { I } 44 \text { chronic pain of cancer } \\
\text { origin patients with difficulty } \\
\text { tolerating oral morphine }\end{array}$ & $\begin{array}{l}\text { Rotation from oral morphine to } \\
\text { transdermal fentanyl (efficacy ratio, } 1: 78 \text { ) }\end{array}$ & $\begin{array}{l}\text { Conversion ratio of oral } \\
\text { morphine to transdermal } \\
\text { fentanyl } \\
\text { Pain control } \\
\text { Reduction in morphine } \\
\text { AEs } \\
\text { Use of rescue analgesia }\end{array}$ \\
\hline Schriek ${ }^{142}$ & Case series & $\begin{array}{l}\text { Three advanced chronic pain } \\
\text { of cancer origin patients }\end{array}$ & $\begin{array}{l}\text { Rotation to transdermal buprenorphine } \\
\text { after failure of step I or step II opioids }\end{array}$ & $\begin{array}{l}\text { Pain control } \\
\text { Tolerability }\end{array}$ \\
\hline Grilo et $\mathrm{a}^{57}$ & Case series & $\begin{array}{l}67 \text { rheumatologic chronic pain } \\
\text { of noncancer patients with pain } \\
\text { uncontrolled with morphine }\end{array}$ & $\begin{array}{l}\text { Opioid rotation: } \\
\text { Oral SR morphine to transdermal fentanyl } \\
\text { Oral SR morphine to oral SR hydromorphone } \\
\text { Other rotations }\end{array}$ & Change in pain severity (VAS) \\
\hline Moryl et a $\left.\right|^{35}$ & $\begin{array}{l}\text { Prospective } \\
\text { case series }\end{array}$ & $\begin{array}{l}\text { I } 3 \text { chronic pain of cancer origin } \\
\text { patients with pain uncontrolled } \\
\text { with methadone }(6-80 \mathrm{mg} / \mathrm{h})\end{array}$ & $\begin{array}{l}\text { First opioid rotation to hydromorphone } \\
\text { (initial dose: I-6 mg/h); morphine } \\
(60 \mathrm{mg} / \mathrm{h}) ; \text { fentanyl }(250-\mathrm{I}, 500 \mu \mathrm{g} / \mathrm{h}) \\
\text { levorphanol }(4-5 \mathrm{mg} / \mathrm{h}) \\
\text { Dose of second opioid before switch } \\
\text { to methadone: hydromorphone, } \\
7.9-40 \mathrm{mg} / \mathrm{h} ; \text { morphine, } 75 \mathrm{mg} / \mathrm{h} \text {; } \\
\text { fentanyl, I } 25-3,240 \mu \mathrm{g} / \mathrm{h} \text {; } \\
\text { levorphanol, } 5-30 \mathrm{mg} / \mathrm{h}\end{array}$ & $\begin{array}{l}\text { Change in VAS pain } \\
\text { Sedation score } \\
\text { AEs } \\
\text { Patient satisfaction } \\
\text { Reason for opioid rotation } \\
\text { Factors limiting dose } \\
\text { escalation } \\
\text { Reasons for discontinuation } \\
\text { of second opioid }\end{array}$ \\
\hline $\begin{array}{l}\text { Mercadante } \\
\text { et } \mathrm{a}^{28}\end{array}$ & $\begin{array}{l}\text { Prospective } \\
\text { observational } \\
\text { study }\end{array}$ & $\begin{array}{l}52 \text { cancer patients receiving } \\
\text { morphine }\end{array}$ & $\begin{array}{l}\text { Rotated to methadone using a } I: 4, \mathrm{I}: 8 \text {, or } \\
\mathrm{I}: \mathrm{I} 2 \text { methadone:morphine dosing ratio. } \\
\text { Lower ratios were used for patients } \\
\text { on higher morphine doses }\end{array}$ & $\begin{array}{l}\text { Change in VAS pain } \\
\text { AEs }\end{array}$ \\
\hline Kloke et $\mathrm{al}^{34}$ & $\begin{array}{l}\text { Retrospective } \\
\text { chart review }\end{array}$ & $\begin{array}{l}273 \text { chronic pain of cancer } \\
\text { origin patients }\end{array}$ & $\begin{array}{l}\text { Rotation to morphine, fentanyl, } \\
\text { methadone, or buprenorphine }\end{array}$ & $\begin{array}{l}\text { Frequency of opioid rotation } \\
\text { Influence of adjuvants } \\
\text { Risk factors for opioid rotation } \\
\text { Reasons for not } \\
\text { recommending rotation }\end{array}$ \\
\hline $\begin{array}{l}\text { Quang- } \\
\text { Cantagrel } \\
\text { et al }{ }^{55}\end{array}$ & $\begin{array}{l}\text { Retrospective } \\
\text { chart review }\end{array}$ & $\begin{array}{l}86 \text { chronic pain of noncancer } \\
\text { origin patients with pain poorly } \\
\text { controlled by long-acting opioid }\end{array}$ & $\begin{array}{l}\text { Treated sequentially with morphine, } \\
\text { oxycodone, methadone, or transdermal } \\
\text { fentanyl patch until effective, } \\
\text { well-tolerated opioid found }\end{array}$ & $\begin{array}{l}\text { Adequate pain response } \\
(\geq 50 \% \text { reduction in pain }) \\
\text { AEs all }<30 \text { on a } 100 \text {-point } \\
\text { scale }\end{array}$ \\
\hline $\begin{array}{l}\text { Thomsen } \\
\text { et } \mathrm{al}^{33}\end{array}$ & $\begin{array}{l}\text { Retrospective } \\
\text { analysis }\end{array}$ & $\begin{array}{l}88 \text { chronic pain of noncancer } \\
\text { origin patients in outpatient } \\
\text { setting }\end{array}$ & $\begin{array}{l}3 \text { I rotations from LAO to different LAO: } \\
\text { Morphine to methadone }(n=12) \\
\text { Ketobemidone to morphine }(n=7) \\
\text { Morphine to oxycodone }(n=4) \\
\text { Ketobemidone to oxycodone }(n=3) \\
\text { Oxycodone to methadone }(n=3) \\
\text { Ketobemidone to methadone }(n=2) \\
28 \text { rotations from SAO to LAO: } \\
\text { Ketobemidone to methadone }(n=9) \\
\text { Ketobemidone to morphine }(n=7) \\
\text { Tramadol to morphine }(n=8) \\
\text { Tramadol to methadone }(n=2) \\
\text { Tramadol to ketobemidone }(n=2)\end{array}$ & $\begin{array}{l}\text { Reason for rotation } \\
\text { Changes in dose after } \\
\text { rotation } \\
\text { Pain control (anecdotal) }\end{array}$ \\
\hline $\begin{array}{l}\text { Daeninck } \\
\text { and Bruera }^{143}\end{array}$ & Case series & $\begin{array}{l}\text { Four cancer patients with history } \\
\text { of laxative use: } \\
\text { Case I: breast cancer and history } \\
\text { of visceral and neuropathic pain } \\
\text { Case 2: prostate cancer and history } \\
\text { of bone and neuropathic pain } \\
\text { Case 3: NHL and bilateral } \\
\text { neuropathic leg pain } \\
\text { Case 4: pancreatic cancer } \\
\text { and postprandial back pain }\end{array}$ & $\begin{array}{l}\text { Opioid rotations: } \\
\text { Case I: from hydromorphone twice } \\
\text { daily to methadone } \\
\text { Case 2: from hydromorphone } \\
\text { and carbamazepine to methadone } \\
\text { Case 3: from transdermal fentanyl } \\
\text { patch and hydromorphone for BTP } \\
\text { plus benzodiazepine to methadone } \\
\text { Case 4: from morphine to hydromorphone to } \\
\text { methadone }\end{array}$ & $\begin{array}{l}\text { Change in constipation and } \\
\text { laxative use }\end{array}$ \\
\hline
\end{tabular}


Table I (Continued)

\begin{tabular}{|c|c|c|c|c|}
\hline Study & Design & Participants & Rotation method & Outcomes \\
\hline $\begin{array}{l}\text { Gagnon } \\
\text { et } \mathrm{al}^{26}\end{array}$ & $\begin{array}{l}\text { Observational } \\
\text { study }\end{array}$ & $\begin{array}{l}63 \text { severe chronic pain of } \\
\text { cancer origin patients with pain } \\
\text { uncontrolled with more than } \\
\text { two different strong opioids } \\
\text { (ie, morphine, hydromorphone) }\end{array}$ & $\begin{array}{l}\text { Rotation from morphine SC or } \\
\text { hydromorphone SC to oxycodone SC }\end{array}$ & $\begin{array}{l}\text { Analgesic effect on ESAS } \\
\text { Tolerability of rotations to } \\
\text { oxycodone } \\
\text { Cost of oxycodone SC }\end{array}$ \\
\hline $\begin{array}{l}\text { Bruera } \\
\text { et al }{ }^{144}\end{array}$ & $\begin{array}{l}\text { Retrospective } \\
\text { chart review }\end{array}$ & $\begin{array}{l}\text { I I } 3 \text { chronic pain of cancer origin } \\
\text { patients with pain uncontrolled } \\
\text { with morphine }(n=36) \\
\text { and hydromorphone }(n=77)\end{array}$ & $\begin{array}{l}\text { Opioid rotation: } \\
\text { Hydromorphone SC to methadone } \\
\text { PO/rectal } \\
\text { Morphine PO/SC to hydromorphone } \\
\text { SC/PO } \\
\text { Hydromorphone PO/SC to morphine } \\
\text { PO/SC }\end{array}$ & $\begin{array}{l}\text { Reasons for opioid rotation: } \\
\text { change in analgesic dose and } \\
\text { pain intensity (VAS) after } \\
\text { rotation }\end{array}$ \\
\hline Vigano et al ${ }^{145}$ & Case report & $\begin{array}{l}\text { Neuropathic pain patient } \\
\text { with pain uncontrolled with } \\
\text { PO morphine }\end{array}$ & $\begin{array}{l}\text { First rotation: } \\
\text { Morphine to hydromorphone, with dose } \\
\text { increase: from I } 40 \mathrm{mg} / \mathrm{d}(\mathrm{MEDD}=280 \text { ) } \\
\text { PO to } 210 \mathrm{mg} / \mathrm{d}(\mathrm{MEDD}=1050) \mathrm{SC} \text {; } \\
\text { plus amitriptyline ( } 25-50 \mathrm{mg} \mathrm{PO} \text { ), } \\
\text { dexamethasone (6 mg PO, three times } \\
\text { daily), metoclopramide SC I0 mg q4h, } \\
\text { cisapride } 10 \mathrm{mg} \text { PO four times daily } \\
\text { Second rotation: } \\
\text { Hydromorphone to methadone } 90 \mathrm{mg} \text { PO } \\
\text { (MEDD=36); major increase at } 4 \text { months } \\
\text { ( } \leq \mathrm{I}, 200 \text { mg/24 h (MEDD=480) } \\
\text { Third rotation: } \\
\text { Methadone to hydromorphone (600-900 } \\
\text { mg/24 h MEDD=3,000-4,950) }\end{array}$ & $\begin{array}{l}\text { Improvement in functional } \\
\text { performance (ESAS) } \\
\text { Assessment of pain (VAS) and } \\
\text { cognitive function (MMSQ) }\end{array}$ \\
\hline $\begin{array}{l}\text { de Stoutz } \\
\text { et } \mathrm{al}^{31}\end{array}$ & $\begin{array}{l}\text { Retrospective } \\
\text { chart review }\end{array}$ & $\begin{array}{l}\text { I9I chronic pain of cancer } \\
\text { origin patients }\end{array}$ & $\begin{array}{l}\text { First opioid rotation for each patient: } \\
\text { from morphine, hydromorphone, } \\
\text { methadone, diamorphine, and fentanyl to } \\
\text { new opioid (morphine, hydromorphone, } \\
\text { methadone, diamorphine, and fentanyl) }\end{array}$ & $\begin{array}{l}\text { MEDD, patient-assessed } \\
\text { symptoms (VAS and ESAS), } \\
\text { and cognitive function } \\
\text { (MMSQ) before and after } \\
\text { opioid rotation }\end{array}$ \\
\hline
\end{tabular}

Note: aCodeine Contin is not available in the United States.

Abbreviations: AE, adverse event; BPI, Brief Pain Inventory; BTP, breakthrough pain; CR, controlled release; d, days; DDOM, daily dose of oral morphine; DDOMET, daily dose of oral methadone; ER, extended release; ESAS, Edmonton Symptom Assessment Scale; h, hours; IR, immediate release; IV, intravenous; LAO, long-acting opioid; MDAS, Memorial Delirium Assessment Scale; MED, morphine equivalent dose; MEDD, morphine equivalent daily dose; MMEDR, morphine/methadone dose ratio; MMSQ, Mini-Mental Status Questionnaire; n, number of patients; NHL, non-Hodgkin lymphoma; NP, neuropathic pain; NRS, Numerical Rating Scale; NVRS, Numerical Verbal Rating Score; PCA, patient-controlled analgesia; PGIC, patient's global impression of change; PO, by mouth; PRN, as needed; QOL, quality of life; SAO, short-acting opioid; SC, subcutaneous; SR, slow release; STAS, Schedule for Team Assessment Scale; VAS, Visual Analog Scale; q7d, every 7 days; q3h, every 3 hours; q4h, every 4 hours; q8h, every 8 hours.

to reduce the potential impact of trial confounders through inclusion and exclusion criteria. Some of the populations presented in clinical trials are rotated either to a preselected opioid without regard to individual patient characteristics that might influence opioid choice or dose, or to a different opioid without any clearly stated criteria for choosing one agent over another. ${ }^{12,25-57}$

Examination of a 2010 study illustrates the shortcomings of clinical trial data for guiding opioid prescribing practices. ${ }^{40}$ In this open-label, prospective study, patients with chronic pain of cancer or noncancer origin $(n=326)$, which was not controlled by a long-acting opioid, were rotated to morphine immediate release (IR) 5 or $10 \mathrm{mg}$ every 4 hours until adequate pain relief was achieved; they were then switched to a long-acting opioid different from baseline. The choice of the long-acting opioid used for rotation was left to the discretion of the investigator. In all, $70 \%$ of patients achieved adequate pain control after switching to morphine IR; after the subsequent rotation to a substitute long-acting opioid, the mean proportion of patients reporting breakthrough pain decreased from $73 \%-93 \%$ to $29 \%-49 \%$, depending on the long-acting opioid. However, patients were excluded if they were on high doses of opioids, had a history of substance abuse, or had psychiatric, pulmonary, renal, and/or hepatic comorbidities.

Upon consideration, it becomes apparent that data from studies such as this, while of value, may be difficult to extrapolate to clinical practice. In a chronic pain practice most 
physicians, either knowingly or unknowingly, will approach a patient's treatment individually, using an "n of 1" approach. ${ }^{58}$ When prescribing opioids, this approach may start with an opioid that the physician is familiar and comfortable with and that has shown efficacy in the past; however, tailoring therapy will ultimately require consideration of the individual patient in ways that are not sufficiently addressed by clinical trials. Since clinical trials deal with distributions of a large number of patients whereas individual practitioners deal with individual patients, the " $n$ of 1 trial" is a more empiric and common approach to treatment.

Case series have described a process wherein patients are prescribed sequential trials of up to five individual opioids in search of an agent that is effective and sufficiently well tolerated. ${ }^{55}$ However, the selection of agents and the sequence in which they are prescribed were not defined, leaving the reader without clear guidance. ${ }^{55}$ In addition, published case series typically do not provide specific information about patients' health status, making it difficult to estimate how certain patient characteristics may have influenced the outcomes observed following rotation. In short, rotation methodology presented in published studies or case series appears to be fixed or random rather than patient-specific.

\section{Selecting an opioid for rotation: patient characteristics}

Chronic pain care must begin with a careful patient assessment that includes a complete history and physical examination to establish a clear pain diagnosis to support a rational multimodal treatment program that might include opioids. Before initiating treatment, clinicians should assess the risk of opioid abuse and the potential for idiosyncratic reactions to opioids by inquiring about previous therapeutic experience with opioids, previous use of sedating prescription or overthe-counter medications, and any previous substance abuse by the patient or family members. ${ }^{7-9}$

A thorough patient history may also include very simple information indicating the presence or absence of genetic anomalies that might influence response and tolerability. For example, about $10 \%$ of the white population have impaired function of the cytochrome (CYP) P450 2D6 enzyme and consequently cannot efficiently metabolize codeine to its active metabolite, morphine. Patients with a history of inadequate response to codeine should be switched with great caution from codeine to a substitute opioid that is not metabolized by CYP2D6 (eg, morphine, fentanyl, oxymorphone) because these patients may not have developed opioid tolerance during previous treatment. ${ }^{8,59}$
When assessing patients, it is important to remember that most patients with chronic pain have more than three specific and individual pain problems at their first visit, making careful assessment a significant challenge. ${ }^{60,61}$ Factors to be considered when selecting a substitute opioid include patient characteristics, comorbidities, concurrent medications, and adverse effects of the opioid being replaced, as summarized in Table 2.

\section{Demographic factors}

Successful pain management may require an understanding of demographic characteristics (eg, age, sex, race) that influence the effectiveness or tolerability of opioid therapy. Clinicians contemplating implementation of opioid rotation should consider the following: 1) potential reduction in clearance of morphine, oxycodone, fentanyl, and oxymorphone has been reported in elderly patients; 2) aging is associated with higher steady-state concentrations of water-soluble drugs and increased half-life of fat-soluble drugs; and 3) potential for higher steady-state concentration of drugs may necessitate dose adjustments (eg, lower doses; longer interval between doses) to maintain an appropriate balance between long-term analgesia and the risk for adverse events. ${ }^{2}$ As a result, older patients may experience similar analgesia at a lower opioid dose $^{22}$ and have a greater risk for respiratory depression. ${ }^{10}$

Women are more sensitive to the effects of $\kappa$ agonists $^{21}$ and are generally more likely than men to experience nausea and vomiting from opioids. ${ }^{10}$ Clearance of oxycodone ${ }^{62}$ and hydromorphone ${ }^{63}$ may be reduced in women, making dosage adjustments necessary. Patients of Chinese origin have increased clearance of morphine compared with white patients. Clearance of hydrocodone may be altered in Asian or black patients. ${ }^{24}$

\section{Comorbidities}

\section{Cardiovascular comorbidities}

In patients with heart failure, particular care must be taken with methadone and caution should be used with morphine, oxycodone, and oxymorphone. ${ }^{23}$ Some patients who are placed on chronic methadone therapy for pain management may be at increased risk for development of a prolonged QT interval or may already have a congenital QT prolongation. ${ }^{64}$ This could influence rotation to methadone as an alternative. The Cardiac Expert Panel of the Center for Substance Abuse Treatment (CSAT) recommends the following: 1) informing patients of the arrhythmia risk associated with methadone; 2) asking about any history of structural heart disease, arrhythmia, and 


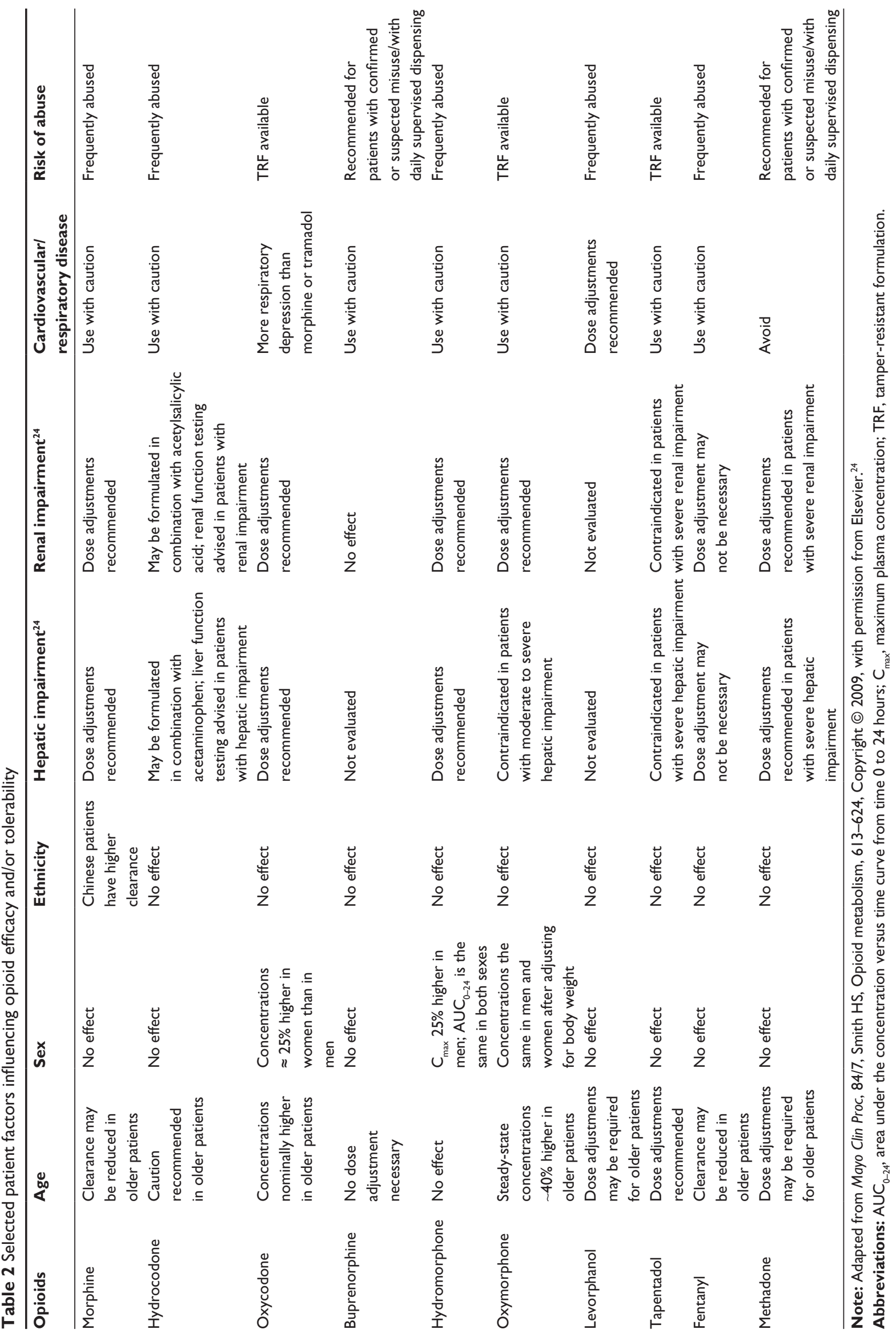


syncope; 3) obtaining a pretreatment electrocardiogram (ECG) for all patients to measure the QT interval and a follow-up ECG within 30 days and annually; 4) avoiding interactions between methadone and other drugs that possess QT interval-prolonging properties or slow the elimination of methadone; and 5) reducing or discontinuing methadone if the QT interval exceeds 500 milliseconds. ${ }^{64}$ Similar but less detailed precautions to avoid arrhythmias with methadone are recommended in the American Society of Interventional Pain Physicians (ASIPP) and American Pain Society (APS)/American Academy of Pain Medicine (AAPM) chronic noncancer pain guidelines. ${ }^{7,9}$

Tramadol has been recommended ahead of nonsteroidal anti-inflammatory drugs for patients with significant cardiovascular risk $^{65}$ and a similar case might be argued for tapentadol. Clinicians may also consider fentanyl, morphine, or oxycodone for these patients because none of these opioids is a significant cause of QT prolongation. ${ }^{66-68}$

\section{Hepatic and renal impairment}

Additional considerations for opioid rotation include the effects of hepatic and renal impairment on opioid dosing recommendations (Table 2). The US Food and Drug Administration (FDA) recommends assessment of hepatic function based on Child-Pugh ratings (mild, moderate, severe $)^{69}$ and defines moderate and severe renal impairment as a creatinine clearance of $30-50 \mathrm{~mL} /$ minute and $<30 \mathrm{~mL} /$ minute, respectively. ${ }^{70}$ Many opioid drugs undergo hepatic phase I metabolism mediated by the CYP mono-oxygenases (primarily CYP3A4 and CYP2D6), ${ }^{71}$ enzymes that produce both active and inactive metabolites that vary among commonly used opioid agents (Table 3 ). Moreover, metabolism of opioids by CYP3A4 produces major metabolites of certain opioids that exhibit $>30$-fold higher (eg, hydrocodone produces norhydrocodone) and lower (eg, buprenorphine produces norbuprenorphine) affinity for the $\mu$-opioid receptor. ${ }^{71}$ Thus, for patients with

Table 3 Characteristics of commonly used opioids

\begin{tabular}{|c|c|c|c|c|c|c|}
\hline Opioid & $\begin{array}{l}\text { Receptor } \\
\text { binding }\end{array}$ & $\begin{array}{l}\text { Routes of } \\
\text { administration }\end{array}$ & $\begin{array}{l}\text { Metabolic } \\
\text { pathway }\end{array}$ & Ceiling dose & Onset of effect & $\begin{array}{l}\text { Duration } \\
\text { of effect }\end{array}$ \\
\hline Morphine & $\mu, \kappa$ (weak) & $\begin{array}{l}\text { Oral tablet, oral } \\
\text { liquid, intramuscular } \\
\text { or subcutaneous, } \\
\text { epidural or intrathecal, } \\
\text { intravenous, rectal }\end{array}$ & Glucuronidation & None & NA & ER or IR \\
\hline Hydrocodone & $\mu, \kappa$ & Oral & CYP2D6 & $\begin{array}{l}\text { Yes for combination } \\
\text { products, no for } \\
\text { pure hydrocodone }\end{array}$ & Rapid & ER or IR \\
\hline Oxycodone & $\mu, \kappa$ (strong) & Oral, rectal & $\begin{array}{l}\text { CYP3A4 } \\
\text { CYP2D6 }\end{array}$ & $\begin{array}{l}\text { Yes for combination } \\
\text { product, no for } \\
\text { pure oxycodone }\end{array}$ & Rapid & ER or IR \\
\hline Buprenorphine & $\begin{array}{l}\mu \text { (antagonist), } \\
\kappa \text { (agonist, } \\
\text { weak partial) }\end{array}$ & $\begin{array}{l}\text { Transdermal, } \\
\text { transmucosal }\end{array}$ & $\begin{array}{l}\text { CYP3A4, } \\
\text { glucuronidation }\end{array}$ & Yes & Slow & Long \\
\hline Hydromorphone & $\begin{array}{l}\mu, \kappa \text { (weak), } \\
\delta \text { (weak) }\end{array}$ & $\begin{array}{l}\text { Oral, intramuscular } \\
\text { or subcutaneous, } \\
\text { intravenous, rectal }\end{array}$ & Glucuronidation & None & $\mathrm{N} / \mathrm{A}$ & ER or IR \\
\hline Oxymorphone & $\mu$ & Oral, intravenous, rectal & Glucuronidation & None & $N / A$ & ER or IR \\
\hline Levorphanol & $\mu, \kappa, \delta$ & Oral & Glucuronidation & $6-12 \mathrm{mg} / \mathrm{d}$ & Rapid & Long \\
\hline Tapentadol & $\mu, 5-\mathrm{HT}, \mathrm{NE}$ & Oral & $\begin{array}{l}\text { Glucuronidation } \\
\text { CYP2C9 (minor) } \\
\text { CYP2C19 (minor) }\end{array}$ & $500 \mathrm{mg} / \mathrm{d}$ & Slow & ER or IR \\
\hline Fentanyl & $\mu, \kappa$ (weak) & $\begin{array}{l}\text { Transdermal, } \\
\text { transmucosal, } \\
\text { intranasal, intravenous }\end{array}$ & CYP3A4 & None & $\begin{array}{l}\text { Very rapid (transmucosal, } \\
\text { intravenous) } \\
\text { Very slow (transdermal) }\end{array}$ & $\begin{array}{l}\text { Very short } \\
\text { Very long } \\
\text { (transdermal) }\end{array}$ \\
\hline Methadone & $\begin{array}{l}\mu, \kappa \text { (weak), } \\
\delta \text { (strong), } \\
\text { NMDA }\end{array}$ & Oral & $\begin{array}{l}\text { CYP3A4 } \\
\text { CYP2B6 } \\
\text { CYP2C8 } \\
\text { CYP2C19 } \\
\text { CYP2D6 } \\
\text { CYP2C9 }\end{array}$ & None & Slow & Long \\
\hline
\end{tabular}

Abbreviations: 5-HT, serotonin; CYP, cytochrome P450; d, day; ER, extended release; IR, immediate release; N/A, not applicable; NE, norepinephrine; NMDA, N-methylD-aspartate. 
hepatic or renal impairment undergoing pain management with opioid A, clinicians may consider the following guidance: 1) dose adjustments are required or recommended with a number of opioids, including morphine, oxycodone, oxymorphone, and hydromorphone in patients with renal

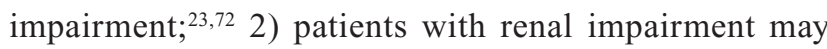
be rotated to fentanyl or buprenorphine, which are less affected by renal impairment; ${ }^{72,73} 3$ ) tapentadol, tramadol, and methadone should be administered with great caution in patients with severe hepatic or renal impairment; ${ }^{23,62}$ and 4) consider rotation to fentanyl in patients with hepatic impairment, which appear not to alter levels of this opioid. ${ }^{74}$

\section{Risk of opioid abuse}

Patients prescribed opioids may exhibit inappropriate behaviors during treatment that warrant rotation to an alternate opioid. However, it is critical for practitioners to understand that treating a patient with an active addictive disorder (without treating this disorder) with scheduled medications is a federal felony. ${ }^{75}$ Therefore, patients with inappropriate behaviors must be evaluated for substance abuse. If substance abuse is found and the patient has serious pain and scheduled medications are considered an appropriate treatment, cotreatment with a substance use disorder specialist is essential.

Behaviors that are concerning and could suggest a substance use disorder include obtaining opioids from sources other than the prescribing physician, using more opioid than prescribed, drug seeking (reporting lost pills, requesting higher doses), and tampering with medications by either crushing them for inhalation or attempting to dissolve them in fluids for intravenous use or to swallow as a solution. Using less opioid than prescribed may also suggest misuse because the patient may be selling or otherwise misdirecting his supply. Previous abuse of other substances is a clear warning that the patient may also abuse any opioids prescribed. ${ }^{15}$

If tampering is a concern, and because all opioids have the potential for abuse, clinicians may consider rotation to a formulation that resists crushing or extraction in fluids. This consideration should be done concurrently with psychological and psychiatric counseling. Oxycodone controlled release (CR), oxymorphone extended release (ER), and tapentadol ER are each available in formulations that resist crushing and dissolution in fluids. ${ }^{76}$ Numerous other products that have various approaches to abuse deterrence and tamper resistance are in current production and study. The FDA is encouraging opioid manufacturers to develop formulations with features resistant to abuse. ${ }^{77}$
Strategies for addressing misuse or addiction may include structured opioid therapy with heightened monitoring, more frequent dispensing of small quantities of opioid, and witnessed administration. ${ }^{78}$ A structured trial of methadone or buprenorphine may be indicated if structured therapy with other opioids is associated with continued misuse. ${ }^{78}$ Methadone has demonstrated efficacy in patients with chronic pain $;{ }^{39}$ however, its use for opioid maintenance in substance use disorders is falling out of favor. ${ }^{79}$ Methadone, with its complicated metabolism and potential cardiotoxic effects, has an increased propensity for overdose death. ${ }^{80}$ This makes methadone a less preferred first choice for patients requiring opioid rotation as part of long-term opioid therapy. Moreover, patients may believe that methadone is reserved for addicts and may resist taking it for fear of the stigma associated with its use. ${ }^{81}$

However, in a responsible and reliable patient who is known to the practitioner, and in the hands of a clinician who is knowledgeable and experienced with the drug, methadone can be an option. In a retrospective observational study, there was no excess mortality observed in nearly 30,000 Veterans Administration (VA) patients treated with methadone compared with nearly $80,000 \mathrm{VA}$ patients treated with long-acting morphine. ${ }^{82}$ However, because this study was not randomized, the populations treated with methadone and with morphine may not have been equivalent, and because these patients were treated within the VA system, the training of prescribers and quality of monitoring may not have been representative of the standard of care received by patients in the general population. ${ }^{82}$

As an alternative to methadone, buprenorphine has shown analgesic efficacy, either singly ${ }^{83}$ or in formulations combining buprenorphine with naloxone (to discourage intravenous abuse). The use of buprenorphine appears not to be accompanied by the stigma associated with methadone and may therefore be more acceptable to patients. ${ }^{84}$ Although there are data suggesting that buprenorphine may be less attractive for abuse compared with methadone ${ }^{85}$ and that buprenorphine/naloxone is less attractive for abuse compared with buprenorphine alone, ${ }^{86}$ there is also more recent evidence showing that buprenorphine/naloxone is being diverted in record numbers. ${ }^{87,88}$ This suggests that any assumption that buprenorphine or buprenorphine/naloxone is less likely than methadone to be abused remains to be proven; it also suggests that abuse liability is a product of multiple factors (eg, availability, cost, street reputation) that includes factors that cannot be easily measured in controlled experiments. ${ }^{89}$ 


\section{Selecting an opioid for rotation: opioid characteristics Receptor binding profile}

Opioid receptors are widely distributed throughout the central nervous system and include $\mu$-receptors, located mainly in the brainstem and medial thalamus; $\delta$-receptors in limbic areas, brainstem, and spinal cord; and $\kappa$-receptors, found predominantly in the brain..$^{90}$ Each of these opioid receptors modulates pain through a similar molecular mechanism that involves a $\mathrm{G}$ protein-coupled signal transduction pathway that causes a block in calcium channel conductance and the release of pain mediators (eg, glutamate, substance P, calcitonin gene-related peptide). ${ }^{90,91}$ At usual doses, some opioid agents exhibit selectivity for $\mu$-receptors; the relative effects of differences among $\mu$-receptors may result in different mechanisms of response. ${ }^{92}$ However, other opioid agents exhibit mixed $\mu / \kappa$-agonist (eg, morphine), $\mu / \kappa / \delta$-agonist (eg, hydromorphone, levorphanol, methadone), or mixed agonist/antagonist activity (eg, buprenorphine) (Table 3). If a patient does not respond to or tolerate an opioid, clinicians may consider rotation to a substitute opioid with a different binding profile.

Tapentadol and tramadol target the opioid receptors to a lesser extent than pure opioids, exerting some of their analgesic effects through serotonin-norepinephrine reuptake inhibition. ${ }^{62,93}$ Patients experiencing pain with a neuropathic component or who have difficulty tolerating a pure opioid agonist may experience adequate analgesia with improved tolerability with one of these agents. However, mixed targeting of opioid and serotonergic receptors (ie, 5-hydroxytryptamine receptors) and adrenergic receptors (ie, norepinephrine receptors) may increase the risk for serotonin syndrome in a patient taking other serotonergic medications. ${ }^{94,95}$

Several opioids function as mixed opioid agonistsantagonists (oxycodone-naloxone, buprenorphine), with the antagonist component blunting adverse events or offering less reinforcement of the positive subjective effects associated with abuse. Although there is no physiologic ceiling dose for most opioids (eg, morphine, hydromorphone, oxymorphone, fentanyl, methadone), there is some evidence that opioid efficacy for mixed agonists-antagonists may be blunted above a certain dose. ${ }^{96}$

\section{Route of administration}

The availability of different formulations provides alternate routes of administration (eg, transdermal or transmucosal and oral) and may facilitate opioid rotation. For example, in patients with chronic pain of cancer origin, morphine is the most often considered opioid for pain relief. ${ }^{97}$ However, a patient may have problems that may complicate oral administration (eg, dysphagia, aspiration, oral cancers). In this setting, clinicians may consider rotation to a transdermal patch (Table 1) that can be administered despite swallowing difficulties. A transdermal patch may also be appropriate, in a monitored setting, for a patient who has a reduction in cognition and chronic pain. If the patient experiences sweating or skin irritation that causes a problem with a transdermal patch, subcutaneous, intramuscular, intravenous, transmucosal, or rectal administration can be used if the patient is at the end of life.

\section{Metabolic pathway and DDIs}

Opioid agents undergo phase II metabolism through the formation of active and inactive glucuronide conjugates, mediated primarily by the membrane-bound enzyme uridine $5^{\prime}$-diphospho-glucuronosyltransferase-2B7. ${ }^{98}$ When a patient requires opioid rotation, clinicians may consider the following: 1) severe renal impairment may increase the plasma concentration of active metabolites of morphine (eg, morphine-6-glucuronide) and the potentially neuroexcitatory 3-glucuronide metabolite of morphine; ${ }^{99} 2$ ) consider rotation to other opioids (eg, fentanyl, hydromorphone) that are little affected by renal impairment; ${ }^{100}$ and 3) consider the need for opioid dose adjustments in elderly patients to accommodate declining renal function and prevent the occurrences of adverse events.

Patients seeking treatment for relief of chronic pain often present with comorbidities and may require coadministration of opioids with other systemically-acting drugs, resulting in unwanted DDIs. ${ }^{23}$ In these patients, clinicians may consider the following: 1) opioids metabolized by CYP450 enzymes (eg, CYP2D6, CYP3A4) are associated with the potential for numerous DDIs (eg, reduced or enhanced opioid effects) (Table 4);2) the prevalence of opioid-related DDIs was greater in women (approximately $31 \%$ versus $22 \%$ ) but similar across all age groups (range, $18-34$ to $\geq 65$ years); and 3) the majority of DDIs (approximately 68\%-71\%) were associated with coadministration of drugs that inhibited CYP2D6 rather than drugs that inhibited CYP3A4 (approximately $28 \%-29 \%){ }^{101}$ Thus, patients using hydrocodone should be monitored for potentially increased or decreased opioid effects when coadministered inducers or inhibitors, respectively, of CYP3A4. ${ }^{102}$ Alternatively, if effective management of medically complicated patients requires coadministration of drugs that inhibit CYP2D6, clinicians 
Table 4 Potential for DDls associated with disruption of key cytochrome P450 enzymes

\begin{tabular}{|c|c|c|c|}
\hline \multirow[t]{2}{*}{ Opioid } & \multicolumn{3}{|c|}{ Analgesic effects of DDls } \\
\hline & Induction of CYP3A4 & Inhibition of CYP3A4 & Inhibition of CYP2D6 \\
\hline Morphine $^{a}$ & No likely clinical consequences & No likely clinical consequences & N/A \\
\hline Hydrocodone & $\begin{array}{l}\text { Potential increase in opioid effects; } \\
\text { patient monitoring recommended }\end{array}$ & $\begin{array}{l}\text { Potential decrease in opioid effects; } \\
\text { patient monitoring recommended }\end{array}$ & N/A \\
\hline Oxycodone & $\begin{array}{l}\text { Decrease in opioid effects; avoid } \\
\text { combination when possible }\end{array}$ & $\begin{array}{l}\text { Increase in opioid effects (black box } \\
\text { warning); avoid combination }\end{array}$ & $\begin{array}{l}\text { Potential decrease in } \\
\text { opioid effects }\end{array}$ \\
\hline Oxymorphone ${ }^{a}$ & N/A & $\mathrm{N} / \mathrm{A}$ & N/A \\
\hline Buprenorphine & Decrease in opioid effects & Increase in opioid effects & N/A \\
\hline Levorphanol $^{\mathrm{a}}$ & N/A & $\mathrm{N} / \mathrm{A}$ & N/A \\
\hline Fentanyl & $\begin{array}{l}\text { Decrease in opioid effects; avoid } \\
\text { combination when possible }\end{array}$ & $\begin{array}{l}\text { Increase in opioid effects (black box } \\
\text { warning); avoid combination }\end{array}$ & N/A \\
\hline Methadone & $\begin{array}{l}\text { Decrease in opioid effects; avoid } \\
\text { combination }\end{array}$ & $\begin{array}{l}\text { Increase in opioid effects; avoid } \\
\text { combination when possible }\end{array}$ & $\begin{array}{l}\text { Increase in opioid effects; } \\
\text { avoid combination }\end{array}$ \\
\hline
\end{tabular}

Notes: aDrugs metabolized primarily by UGT2B7 (Phase II) and not likely to be associated with significant DDIs caused by alterations to CYP3A4 and CYP2D6. For more information on Buprenorphine see McCance-Katz et al. ${ }^{146}$ Copyright (C) 20II. Adapted from The American Journal of Managed Care. Overholser BR, Foster DR. Opioid pharmacokinetic drug-drug interactions. Am J Manag Care. 20I I;I7(suppl I I):S276-S287. ${ }^{147}$

Abbreviations: CYP, cytochrome P450; DDIs, drug-drug interactions; N/A, not applicable.

may consider opioids that are not substrates for this enzyme (eg, fentanyl, oxymorphone).

In addition to CYP450-mediated DDIs, clinicians considering rotation to certain opioids (eg, fentanyl, tapentadol) should instruct patients regarding the following: 1) additive effects of central nervous system depressants (eg, fentanyl in combination with alcohol, sedatives) ${ }^{103}$ 2) constipating effects of tricyclic antidepressants; ${ }^{104} 3$ ) increased risk for seizures with tramadol or tapentadol in combination with a monoamine oxidase inhibitor antidepressant; 4) increased risk for serotonin syndrome with tapentadol or tramadol in combination with serotonin reuptake inhibitors; and 5) risks of central nervous system depressant effects associated with the addition of benzodiazepines. . $2,80,93,105,106^{-10}$

\section{Adverse events}

Discussion of the many adverse events and side effects from the use of opioids is beyond the scope of this article. However, a few will be discussed to give examples of why opioid rotation may be helpful when these issues present themselves.

\section{Constipation}

Clinical results indicate that inadequately controlled constipation occurs in approximately $10 \%-60 \%$ of patients undergoing opioid treatment for chronic pain of cancer and noncancer origin. ${ }^{107,108}$ For patients on an opioid who complain of constipation, the following guidance may be useful: 1) prescribing a bowel regimen is a necessity with every opioid; however, an effective bowel regimen may or may not overcome the relative propensity of the specific opioid to cause constipation; ${ }^{107,109} 2$ ) if constipation continues to limit quality of life, opioid antagonists (eg, methylnaltrexone, lubiprostone) and upcoming combination products, such as prolonged-release oxycodone plus prolonged-release naloxone (a $\mu$-receptor opioid with limited systemic bioavailability), may improve bowel function; ${ }^{110} 3$ ) transdermal fentanyl has been associated with a significantly lower rate of constipation compared with oral morphine, ${ }^{111,112}$ making it a potential option for opioid-experienced patients with a history of constipation during opioid therapy; and 4) tapentadol IR exhibits weaker $\mu$-receptor activity compared with pure opioid agonists and may be associated with a lower incidence of constipation than oxycodone. ${ }^{46,94,110}$

\section{Nausea and vomiting}

Inadequately controlled nausea and vomiting is frequently reported in patients receiving opioids for pain management. ${ }^{107}$ For example, tapentadol has displayed effective analgesia with a decreased risk for nausea and vomiting compared with oxycodone. ${ }^{113,114} \mathrm{Clinicians}$ may therefore consider rotation to tapentadol in patients who complain of nausea and vomiting after initiation/rotation to other opioids.

\section{Equianalgesic dose conversion}

There are two general approaches to opioid conversion for clinicians conducting opioid rotation. Some clinicians may prefer to calculate dose conversions themselves using package inserts and/or with reference to the published literature. ${ }^{115}$ Second, clinicians can use an online dose calculator. These include the Johns Hopkins Opioid Conversion Program calculator, sponsored by the Sidney Kimmel 
Comprehensive Cancer Center at Johns Hopkins; ${ }^{116}$ the GlobalRPH calculator, sponsored by Novartis Pharmaceuticals Corporation (Basel, Switzerland), ${ }^{117}$ and the Practical Pain Management Opioid calculator, sponsored by Vertical Health Media, LLC (Montclair, NJ, USA). ${ }^{118}$ The authors recommend use of the Practical Pain Management Opioid calculator as being the most inclusive of available opioids but advise that any table or calculator be used with caution because recommended equianalgesic doses as shown in dose conversion tables may vary (eg, conversion ratios of oral to parenteral morphine range from 3.1 to $2: 1$ to $6: 1$ ). ${ }^{119}$ Further, it is the experience of the authors that this conversion table reflects how they apply dose conversion in their own practices. In addition, conversion tables do not fully consider the contributions that individual patient characteristics, comorbidities, and concurrent medications may have on opioid dose. In the opinion of the authors and other authorities on pain management, these tables and converters are not based on good science and research, being derived mainly from expert opinion or single-dose studies in patients with acute pain of noncancer origin. ${ }^{115}$

To account for potential variability of response, clinicians may convert patients from one opioid to another using a two-step guideline developed by an expert panel and presented by Fine and Portenoy. ${ }^{14}$ For step one, the clinician calculates the equianalgesic dose using an online dosage calculator as suggested (eg, Practical Pain Management Opioid calculator). ${ }^{116-118}$ However, no system of dose conversion is perfect, and the difference between package inserts (which may not be based upon the most current or extensive evidence) and other conversion tables may be significant. The initial dose administered, however, should be $25 \%-50 \%$ lower than the calculated equianalgesic dose. The reduction should be closer to $50 \%$ of the calculated dose if the patient is receiving a high dose of the opioid being discontinued or if they are elderly, medically frail, or not white. The reduction should be closer to $25 \%$ in patients without these attributes or if they are switching to a different route of administration of the same opioid. Fine and Portenoy recommend that patients switched to methadone should receive an initial methadone dose $75 \%-90 \%$ lower than the original opioid because higherthan-anticipated potency has been observed in the clinical setting. ${ }^{14}$ The safe use of methadone can be challenging for reasons outlined in Tables 2 and 4.

For step two, clinicians should assess and reassess the patient as appropriate for individual circumstances; this should be done after initiating the substitute opioid to gauge the extent of analgesia on the new opioid, adverse events, and other medical and psychosocial factors that might guide dose adjustments. After this assessment, the dose should be increased $15 \%-30 \%$ if additional analgesia is required or to minimize the risk of withdrawal or other adverse events. ${ }^{14}$ Rescue medication, if provided during titration, should be administered at $5 \%-15 \%$ of the total daily dose of the substitute opioid. ${ }^{14}$

This two-step method may greatly increase the safety of opioid rotation. However, clinicians still need to understand the potential contribution of basic clinical factors when selecting a substitute opioid for rotation and deciding how much to reduce the equianalgesic dose when making the switch. Clinicians who are unclear of the appropriate conversion method for a particular patient should consult a pain specialist, oncologist, or other reliable mentor.

Whenever an opioid is prescribed, an exit strategy should always be considered and discussed with the patient. ${ }^{120}$ Opioid tapering may be undertaken owing to inadequate response or if the patient is suspected of using his opioid inappropriately. ${ }^{7,8}$ As noted in Canadian guidelines, ${ }^{8}$ tapering of an opioid may be accompanied by a reduction in pain and improvements in mood owing, perhaps, to the reduction or elimination of hyperalgesia and withdrawal symptoms; the alleviation of adverse effects, such as sedation or dysphoria; or the psychological interventions that may be implemented in conjunction with the decision to taper. ${ }^{8}$ US guidelines state that an opioid may be tapered using a schedule ranging from a $10 \%$ dose reduction each week to a $25 \%-50 \%$ dose reduction every few days. If possible, patients who abuse their opioid or otherwise have difficulty tapering on their own should be referred to a facility allowing for a structured, supervised approach. ${ }^{7}$

\section{Future directions}

Genetic research may one day simplify the selection of initial and substitute opioids for individual patients. Recent studies have identified functional single-nucleotide polymorphisms (SNPs) in genes encoding receptors (eg, OPRM1 that encodes the $\mu-1$ opioid receptor), transporter proteins (eg, $A B C B 1$ [MDR1] that encodes p-glycoprotein), CYP (eg, CYP2D6) Phase II (eg, UGT2B7) enzymes involved in opioid metabolism, and other genetic changes. ${ }^{121-124}$ Recent studies suggest an association between the presence of these SNPs and altered responsiveness to opioids; although the identification of SNPs presents intriguing possibilities for guiding opioid treatment, a recent genotyping analysis in more than 2,000 patients with cancer who were undergoing opioid treatment of moderate to severe pain found no association between the presence of SNPs (eg, OPRM1, ABCB1,COMT) and opioid dose in patients 
administered morphine, oxycodone, or fentanyl alone. ${ }^{125}$ Moreover, screening for the presence of SNPs of interest may not be available outside major medical centers and is not currently economically feasible in individual clinical practices.

Further, the role of glial cells in the generation of pain and opioid function has become a recent focus. ${ }^{126}$ The effects of glial activation and potential targets to reduce this activation is an exciting new area of pain research.

\section{Summary}

Our review of the literature has identified many factors that can be considered when planning an opioid rotation, in the hope of selecting an opioid less likely to perpetuate the tolerability problems observed with the first opioid. We have compiled these factors into an algorithm to guide the selection of the new opioid for rotation (Figure 1). The authors caution that there are no data to support our proposition that

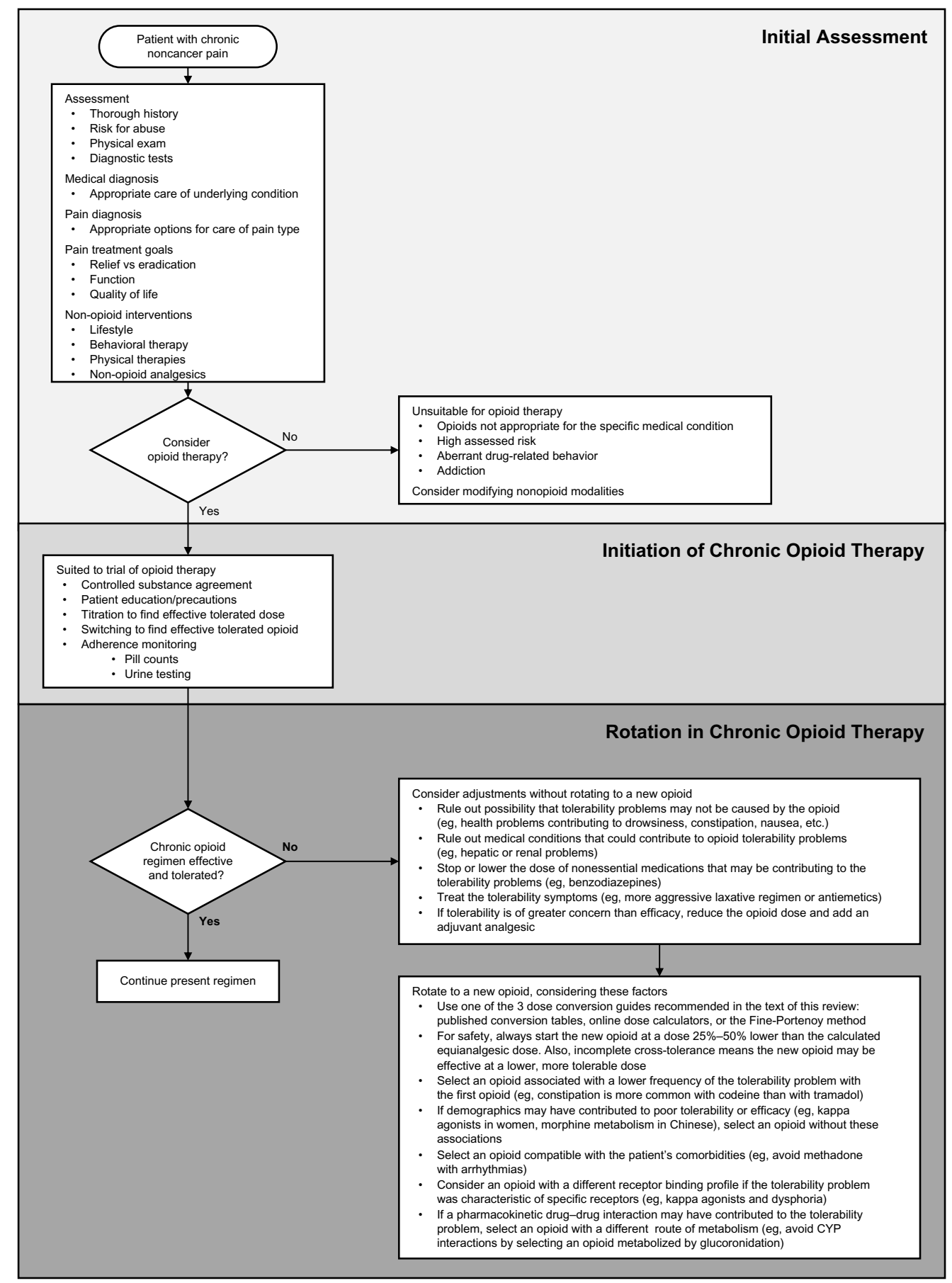

Figure I Algorithm for initial patient assessment and initiation and rotation of opioid therapy. Abbreviation: CYP, cytochrome P450. 
a patient may be more likely to find the new opioid tolerable and effective when it has been selected using a systematic approach to rotation, and it should be noted that nonclinical factors, such as formulary restrictions, may greatly complicate efforts to take such an approach.

Clinically, however, factors such as patient demographics, opioid receptor affinity, and opioid metabolism and so on, should be considered when the new opioid is selected instead of relying on a set protocol or the clinician's standard routine. Moreover, it is important to note that many adverse events associated with opioids are dose related. Consequently, if one rotates a patient from one opioid to another, following the advice to reduce the starting dose of the new opioid by $25 \%-50 \%$ of the calculated equianalgesic dose of the first opioid, this reduction in dose may result in improved tolerability while incomplete cross-tolerance may result in equivalent efficacy. ${ }^{127}$ There is a need for clinical trials to test the value of selecting the opioid for rotation on a systematic basis versus random or arbitrary selection.

\section{Dedication}

This manuscript is dedicated to Dr Howard S Smith, who passed away suddenly before its publication. The profession has lost a gifted clinician and teacher, whose originality, dedication, and kindness were appreciated by his colleagues, students, and patients. His passing is a great loss to the profession of pain and palliative medicine as well as to his friends and acquaintances personally.

\section{Author contributions}

The authors contributed to the literature search design; the analysis and interpretation of the literature reviewed in this manuscript, and to the preparation, review, and final approval to submit the manuscript; independent of the funding organization (Endo Pharmaceuticals Inc., Malvern, PA, USA).

\section{Acknowledgment}

Editorial support for this manuscript was provided by Robert Gatley, MD, Craig D Albright, PhD, and Jeffrey Coleman, MA, of Complete Healthcare Communications, Inc. (Chadds Ford, PA, USA), with funding from Endo Pharmaceuticals Inc. (Malvern, PA, USA).

\section{Disclosure}

Drs Smith and Peppin have served as advisors and consultants for Endo Pharmaceuticals Inc., and Dr Smith has presented research at scientific meetings with reimbursement of associated expenses from Endo Pharmaceuticals Inc.; Dr Peppin is an employee of Mallinckrodt Pharmaceuticals
(St Louis, MO, USA). Editorial support for this review was provided by Complete Healthcare Communications, Inc. (Chadds Ford, PA, USA), with funding from Endo Pharmaceuticals Inc. (Malvern, PA, USA). However, neither Drs Smith nor Peppin, who had complete control over the content of this paper, received any remuneration for developing and writing this review.

\section{References}

1. US Department of Health and Human Services, Centers for Disease Control and Prevention. Health, United States, 2011 with Chartbook on Trends in the Health of Americans. Hyattsville, MD: National Center for Health Statistics; 2011.

2. Dalacorte RR, Rigo JC, Dalacorte A. Pain management in the elderly at the end of life. NAm J Med Sci. 2011;3(8):348-354.

3. World Health Organization. Cancer pain relief. Geneva: World Health Organization; 1996. Available from: http://whqlibdoc.who.int/ publications/9241544821.pdf. Accessed December 5, 2012.

4. American Society of Anesthesiologists Task Force on Acute Pain Management. Practice guidelines for acute pain management in the perioperative setting: an updated report by the American Society of Anesthesiologists Task Force on Acute Pain Management. Anesthesiology. 2004;100(6):1573-1581.

5. AGS Panel on Persistent Pain in Older Persons. The management of persistent pain in older persons. J Am Geriatr Soc. 2002;50(Suppl 6): S205-S224.

6. Management of pain in osteoarthritis and rheumatoid arthritis. In: Simon LS, Lipman AG, Caudill-Slosberg M, et al, editors. Guideline for the Management of Pain in Osteoarthritis, Rheumatoid Arthritis and Juvenile Chronic Arthritis. 2nd ed. Chicago, IL: American Pain Society; 2002:43-77.

7. Chou R, Fanciullo GJ, Fine PG, et al; American Pain Society-American Academy of Pain Medicine Opioids Guidelines Panel. Clinical guidelines for the use of chronic opioid therapy in chronic noncancer pain. J Pain. 2009;10(2):113-130.

8. Kahan M, Mailis-Gagnon A, Wilson L, Srivastava A; National Opioid Use Guideline Group. Canadian guideline for safe and effective use of opioids for chronic noncancer pain: clinical summary for family physicians. Part 1: general population. Can Fam Physician. 2011;57(11):1257-1266, e407-e418.

9. Manchikanti L, Abdi S, Atluri S, et al. American Society of Interventional Pain Physicians (ASIPP) guidelines for responsible opioid prescribing in chronic non-cancer pain: Part 2 - guidance. Pain Physician. 2012;15(suppl 3):S67-S116.

10. Cepeda MS, Farrar JT, Baumgarten M, Boston R, Carr DB, Strom BL. Side effects of opioids during short-term administration: effect of age, gender, and race. Clin Pharmacol Ther. 2003;74(2):102-112.

11. Lötsch J, von Hentig N, Freynhagen R, et al. Cross-sectional analysis of the influence of currently known pharmacogenetic modulators on opioid therapy in outpatient pain centers. Pharmacogenet Genomics. 2009;19(6):429-436.

12. Riley J, Ross JR, Rutter D, et al. No pain relief from morphine? Individual variation in sensitivity to morphine and the need to switch to an alternative opioid in cancer patients. Support Care Cancer. 2006;14(1):56-64.

13. Pergolizzi J, Böger RH, Budd K, et al. Opioids and the management of chronic severe pain in the elderly: consensus statement of an International Expert Panel with focus on the six clinically most often used World Health Organization Step III opioids (buprenorphine, fentanyl, hydromorphone, methadone, morphine, oxycodone). Pain Pract. 2008; 8(4):287-313.

14. Fine PG, Portenoy RK; Ad Hoc Expert Panel on Evidence Review and Guidelines for Opioid Rotation. Establishing "best practices" for opioid rotation: conclusions of an expert panel. J Pain Symptom Manage. 2009;38(3):418-425. 
15. Kahan M, Wilson L, Mailis-Gagnon A, Srivastava A; National Opioid Use Guideline Group. Canadian guideline for safe and effective use of opioids for chronic noncancer pain: clinical summary for family physicians. Part 2: special populations. Can Fam Physician. 2011; 57(11):1269-1276, e419-e428.

16. Manchikanti L, Abdi S, Atluri S, et al. American Society of Interventional Pain Physicians (ASIPP) guidelines for responsible opioid prescribing in chronic non-cancer pain: Part I-evidence assessment. Pain Physician. 2012;15(suppl 3):S1-S65.

17. Webster LR, Fine PG. Review and critique of opioid rotation practices and associated risks of toxicity. Pain Med. 2012;13(4):562-570.

18. Quigley C. Opioid switching to improve pain relief and drug tolerability. Cochrane Database Syst Rev. 2004;3:CD004847.

19. Vissers KC, Besse K, Hans G, Devulder J, Morlion B. Opioid rotation in the management of chronic pain: where is the evidence? Pain Pract. 2010;10(2):85-93.

20. Droney J, Riley J. Recent advances in the use of opioids for cancer pain. J Pain Res. 2009;2:135-155.

21. Gear RW, Miaskowski C, Gordon NC, Paul SM, Heller PH, Levine JD Kappa-opioids produce significantly greater analgesia in women than in men. Nat Med. 1996;2(11):1248-1250.

22. Viganó A, Bruera E, Suarez-Almazor ME. Age, pain intensity, and opioid dose in patients with advanced cancer. Cancer. 1998;83(6) 1244-1250.

23. Smith H, Bruckenthal P. Implications of opioid analgesia for medically complicated patients. Drugs Aging. 2010;27(5):417-433.

24. Smith HS. Opioid metabolism. Mayo Clin Proc. 2009;84(7):613-624.

25. Benítez-Rosario MA, Salinas-Martín A, Aguirre-Jaime A, PérezMéndez L, Feria M. Morphine-methadone opioid rotation in cancer patients: analysis of dose ratio predicting factors. J Pain Symptom Manage. 2009;37(6):1061-1068.

26. Gagnon B, Bielech M, Watanabe S, Walker P, Hanson J, Bruera E. The use of intermittent subcutaneous injections of oxycodone for opioid rotation in patients with cancer pain. Support Care Cancer. 1999;7(4) 265-270.

27. Hale ME, Ahdieh H, Ma T, Rauck R; Oxymorphone ER Study Group 1. Efficacy and safety of OPANA ER (oxymorphone extended release) for relief of moderate to severe chronic low back pain in opioid-experienced patients: a 12-week, randomized, double-blind, placebo-controlled study. J Pain. 2007;8(2):175-184.

28. Mercadante S, Casuccio A, Fulfaro F, et al. Switching from morphine to methadone to improve analgesia and tolerability in cancer patients: a prospective study. J Clin Oncol. 2001;19(11):2898-2904.

29. Morita T, Takigawa C, Onishi H, et al; Japan Pain, Rehabilitation, Palliative Medicine, and Psycho-Oncology (PRPP) Study Group. Opioid rotation from morphine to fentanyl in delirious cancer patients: an open-label trial. J Pain Symptom Manage. 2005;30(1):96-103.

30. Narabayashi M, Saijo Y, Takenoshita S, et al. Opioid rotation from oral morphine to oral oxycodone in cancer patients with intolerable adverse effects: an open-label trial. Jpn J Clin Oncol. 2008;38(4): 296-304.

31. de Stoutz ND, Bruera E, Suarez-Almazor M. Opioid rotation for toxicity reduction in terminal cancer patients. J Pain Symptom Manage. 1995; 10(5):378-384.

32. Bruera E, Sloan P, Mount B, Scott J, Suarez-Almazor M. A randomized, double-blind, double-dummy, crossover trial comparing the safety and efficacy of oral sustained-release hydromorphone with immediate-release hydromorphone in patients with cancer pain. Canadian Palliative Care Clinical Trials Group. J Clin Oncol. 1996; 14(5):1713-1717.

33. Thomsen AB, Becker N, Eriksen J. Opioid rotation in chronic nonmalignant pain patients. A retrospective study. Acta Anaesthesiol Scand. 1999;43(9):918-923.

34. Kloke M, Rapp M, Bosse B, Kloke O. Toxicity and/or insufficient analgesia by opioid therapy: risk factors and the impact of changing the opioid. A retrospective analysis of 273 patients observed at a single center. Support Care Cancer. 2000;8(6):479-486.
35. Moryl N, Santiago-Palma J, Kornick C, et al. Pitfalls of opioid rotation: substituting another opioid for methadone in patients with cancer pain. Pain. 2002;96(3):325-328.

36. Drake R, Longworth J, Collins JJ. Opioid rotation in children with cancer. J Palliat Med. 2004;7(3):419-422.

37. Freye E, Anderson-Hillemacher A, Ritzdorf I, Levy JV. Opioid rotation from high-dose morphine to transdermal buprenorphine (Transtec) in chronic pain patients. Pain Pract. 2007;7(2):123-129.

38. Cheema B, Lagman RL, Walsh D, et al. A prospective study of opioid rotation in pain due to advanced cancer. J Cancer Pain Symptom Palliation. 2008;2(3):39-46

39. Peng P, Tumber P, Stafford M, et al. Experience of methadone therapy in 100 consecutive chronic pain patients in a multidisciplinary pain center. Pain Med. 2008;9(7):786-794

40. Gatti A, Reale C, Luzi M, et al. Effects of opioid rotation in chronic pain patients: ORTIBARN study. Clin Drug Investig. 2010;30(suppl 2): 39-47.

41. Korkmazsky M, Ghandehari J, Sanchez A, Lin HM, Pappagallo M. Feasibility study of rapid opioid rotation and titration. Pain Physician. 2011;14(1):71-82.

42. McDonnell C, Pehora C, Crawford MW. PCA-derived factors that may be predictive of postoperative pain in pediatric patients: a possible role for the PCA ratio. J Opioid Manag. 2012;8(1): 39-44

43. Oldenmenger WH, Lieverse PJ, Janssen PJ, Taal W, van der Rijt CC, Jager A. Efficacy of opioid rotation to continuous parenteral hydromorphone in advanced cancer patients failing on other opioids. Support Care Cancer. 2012;20(8):1639-1647.

44. Ostgathe C, Voltz R, Van Aaaken A, et al. Practicability, safety, and efficacy of a "German model" for opioid conversion to oral levomethadone. Support Care Cancer. 2012;20(9):2105-2110.

45. Benítez-Rosario MA, Feria M, Salinas-Martín A, MartínezCastillo LP, Martín-Ortega JJ. Opioid switching from transdermal fentanyl to oral methadone in patients with cancer pain. Cancer. 2004;101(12):2866-2873.

46. Parsons HA, de la Cruz M, El Osta B, et al. Methadone initiation and rotation in the outpatient setting for patients with cancer pain. Cancer. 2010;116(2):520-528.

47. Walker PW, Palla S, Pei BL, et al. Switching from methadone to a different opioid: what is the equianalgesic dose ratio? J Palliat Med. 2008;11(8):1103-1108.

48. Hanaoka K, Yoshimura T, Tomioka T, Sakata H. [Clinical study of one-day fentanyl patch in patients with cancer pain - evaluation of the efficacy and safety in relation to treatment switch from opioid analgesic therapy]. Masui. 2011;60(2):147-156. Japanese.

49. Kawano C, Hirayama T, Kuroyama M. Dose conversion in opioid rotation from continuous intravenous infusion of morphine hydrochloride injection to fentanyl patch in the management of cancer pain. Yakugaku Zasshi. 2011;131(3):463-467.

50. Leppert W. The role of methadone in opioid rotation-a Polish experience. Support Care Cancer. 2009;17(5):607-612.

51. Davies D, DeVlaming D, Haines C. Methadone analgesia for children with advanced cancer. Pediatr Blood Cancer. 2008;51(3): 393-397.

52. Braiteh F, El Osta B, Palmer JL, Reddy SK, Bruera E. Characteristics, findings, and outcomes of palliative care inpatient consultations at a comprehensive cancer center. J Palliat Med. 2007;10(4):948-955.

53. Clemens KE, Klaschik E. Clinical experience with transdermal and orally administered opioids in palliative care patients - a retrospective study. Jpn J Clin Oncol. 2007;37(4):302-309.

54. Kato K, Mizaki T, Yamazaki S, et al. A study of transdermal fentanyl in cancer pain at Aichi-Cancer Center. Yakugaku Zasshi. 2004;124(5): $287-291$.

55. Quang-Cantagrel ND, Wallace MS, Magnuson SK. Opioid substitution to improve the effectiveness of chronic noncancer pain control: a chart review. Anesth Analg. 2000;90(4):933-937. 
56. Wirz S, Wartenberg HC, Elsen C, Wittmann M, Diederichs M, Nadstawek J. Managing cancer pain and symptoms of outpatients by rotation to sustained-release hydromorphone: a prospective clinical trial. Clin J Pain. 2006;22(9):770-775.

57. Grilo RM, Bertin P, Scotto di Fazano C, et al. Opioid rotation in the treatment of joint pain. A review of 67 cases. Joint Bone Spine. 2002;69(5): 491-494.

58. Guyatt GH, Keller JL, Jaeschke R, Rosenbloom D, Adachi JD, Newhouse MT. The n-of-1 randomized controlled trial: clinical usefulness. Our three-year experience. Ann Intern Med. 1990;112(4): 293-299.

59. Foster A, Mobley E, Wang Z. Complicated pain management in a CYP450 2D6 poor metabolizer. Pain Pract. 2007;7(4):352-356.

60. Chrubasik S, Junck H, Zappe HA, Stutzke O. A survey on pain complaints and health care utilization in a German population sample. Eur J Anaesthesiol. 1998;15(4):397-408.

61. American Academy of Pain Medicine. AAPM facts and figures on pain. Chicago: American Academy of Pain Medicine; 2013. Available from: http://www.painmed.org/PatientCenter/Facts_on_Pain.aspx. Accessed June 6, 2013.

62. OxyContin ${ }^{\circledR}$ (oxycodone $\mathrm{HCl}$ extended release tablets) [prescribing information]. Stamford, CT: Purdue Pharma L.P.; 2013.

63. Dilaudid ${ }^{\circledR}$ (hydromorphone $\mathrm{HCl}$ ) [prescribing information]. Stamford, CT: Purdue Pharma L.P.; 2009.

64. Krantz MJ, Martin J, Stimmel B, Mehta D, Haigney MC. QTc interval screening in methadone treatment. Ann Intern Med. 2009;150(6): 387-395.

65. Antman EM, Bennett JS, Daugherty A, Furberg C, Roberts H, Taubert KA; American Heart Association. Use of nonsteroidal antiinflammatory drugs: an update for clinicians: a scientific statement from the American Heart Association. Circulation. 2007;115(12):1634-1642.

66. Berling I, Whyte IM, Isbister GK. Oxycodone overdose causes naloxone responsive coma and QT prolongation. QJM. 2013;106(1): $35-41$.

67. Kornick CA, Kilborn MJ, Santiago-Palma J, et al. QTc interval prolongation associated with intravenous methadone. Pain. 2003;105(3): 499-506.

68. Cafiero T, Di Minno RM, Di Iorio C. QT interval and QT dispersion during the induction of anesthesia and tracheal intubation: a comparison of remifentanil and fentanyl. Minerva Anestesiol. 2011;77(2):160-165.

69. US Department of Health and Human Services; Food and Drug Administration; Center for Drug Evaluation and Research (CDER); Center for Biologics Evaluation and Research (CBER). Guidance for Industry: Pharmacokinetics in Patients With Impaired Hepatic Function: Study Design, Data Analysis, and Impact on Dosing and Labeling. Rockville, MD: Food and Drug Administration; 2003.

70. US Department of Health and Human Services; Food and Drug Administration; Center for Drug Evaluation and Research (CDER); Center for Biologics Evaluation and Research (CBER). Guidance for Industry: Pharmacokinetics in Patients With Impaired Renal FunctionStudy Design, Data Analysis, and Impact on Dosing and Labeling. Rockville, MD: Food and Drug Administration; 1998.

71. Smith HS. The metabolism of opioid agents and the clinical impact of their active metabolites. Clin J Pain. 2011;27(9):824-838.

72. Davies G, Kingswood C, Street M. Pharmacokinetics of opioids in renal dysfunction. Clin Pharmacokinet. 1996;31(6):410-422.

73. Böger RH. Renal impairment: a challenge for opioid treatment? The role of buprenorphine. Palliat Med. 2006;20(suppl 1):S17-S23.

74. Tegeder I, Lötsch J, Geisslinger G. Pharmacokinetics of opioids in liver disease. Clin Pharmacokinet. 1999;37(1):17-40.

75. US Department of Justice, Drug Enforcement Agency. The Controlled Substances Act, 21 USC $\$ 841$ (b)(C) Prohibited Acts A. Springfield, VA: US Department of Justice, Drug Enforcement Agency; 2013. Available from: http://www.deadiversion.usdoj.gov/21 cfr/ 21 usc $/ 841$. htm. Accessed June 26, 2013.

76. Romach MK, Schoedel KA, Sellers EM. Update on tamper-resistant drug formulations. Drug Alcohol Depend. 2013;130(1-3):13-23.
77. US Department of Health and Human Services, Food and Drug Administration, Center for Drug Evaluation and Research. Guidance for Industry: Abuse-Deterrent Opioids-Evaluation and Labeling. Silver Spring, MD: Center for Drug Evaluation and Research (CDER); 2013. Available from: http://www.fda.gov/downloads/Drugs/ GuidanceComplianceRegulatoryInformation/Guidances/UCM334743. pdf. Accessed June 26, 2013.

78. National Opioid Use Guideline Group. Canadian guideline for safe and effective use of opioids for chronic non-cancer pain. Canada: National Opioid Use Guideline Group (NOUGG); 2010. Available from: http:// nationalpaincentre.mcmaster.ca/opioid/. Accessed September 18, 2013.

79. Mattick RP, Breen C, Kimber J, Davoli M. Methadone maintenance therapy versus no opioid replacement therapy for opioid dependence. Cochrane Database Syst Rev. 2009;(3):CD002209.

80. Webster LR, Cochella S, Dasgupta N, et al. An analysis of the root causes for opioid-related overdose deaths in the United States. Pain Med. 2011;12(supp1 2):S26-S35.

81. Earnshaw V, Smith L, Copenhaver M. Drug addiction stigma in the context of methadone maintenance therapy: an investigation into understudied sources of stigma. Int J Ment Health Addict. 2013;11(1): 110-122.

82. Krebs EE, Becker WC, Zerzan J, Bair MJ, McCoy K, Hui S. Comparative mortality among Department of Veterans Affairs patients prescribed methadone or long-acting morphine for chronic pain. Pain. 2011;152(8):1789-1795.

83. Blondell RD, Ashrafioun L, Dambra CM, Foschio EM, Zielinski AL, Salcedo DM. A clinical trial comparing tapering doses of buprenorphine with steady doses for chronic pain and co-existent opioid addiction. J Addict Med. 2010;4(3):140-146.

84. Schwartz RP, Kelly SM, O'Grady KE, et al. Attitudes toward buprenorphine and methadone among opioid-dependent individuals. Am JAddict. 2008;17(5):396-401.

85. Cicero TJ, Surratt HL, Inciardi J. Use and misuse of buprenorphine in the management of opioid addiction. J Opioid Manag. 2007;3(6): 302-308.

86. Comer SD, Sullivan MA, Vosburg SK, et al. Abuse liability of intravenous buprenorphine/naloxone and buprenorphine alone in buprenorphine-maintained intravenous heroin abusers. Addiction. 2010;105(4):709-718.

87. Yokell MA, Zaller ND, Green TC, Rich JD. Buprenorphine and buprenorphine/naloxone diversion, misuse, and illicit use: an international review. Curr Drug Abuse Rev. 2011;4(1):28-41.

88. Johanson CE, Arfken CL, di Menza S, Schuster CR. Diversion and abuse of buprenorphine: findings from national surveys of treatment patients and physicians. Drug Alcohol Depend. 2012;120(1-3):190-195.

89. Butler SF, Fernandez KC, Chang A, et al. Measuring attractiveness for abuse of prescription opioids. Pain Med. 2010;11(1):67-80.

90. Trescot AM, Datta S, Lee M, Hansen H. Opioid pharmacology. Pain Physician. 2008;11(suppl 2):S133-S153.

91. Al-Hasani R, Bruchas MR. Molecular mechanisms of opioid receptordependent signaling and behavior. Anesthesiology. 2011;115(6): 1363-1381.

92. Pasternak GW. Multiple opiate receptors: déjà vu all over again. Neuropharmacology. 2004;47(suppl 1):312-323.

93. Ultram ${ }^{\circledR}$ ER (tramadol hydrochloride) [prescribing information]. Raritan, NJ: Ortho-McNeil-Janssen Pharmaceuticals, Inc.; 2009.

94. Vadivelu N, Timchenko A, Huang Y, Sinatra R. Tapentadol extendedrelease for treatment of chronic pain: a review. $J$ Pain Res. 2011;4: 211-218.

95. McCarberg B. Tramadol extended-release in the management of chronic pain. Ther Clin Risk Manag. 2007;3(3):401-410.

96. Mercadante S, Ferrera P, Adile C. High doses of oxycodone-naloxone combination may provide poor analgesia. Support Care Cancer. 2011;19(9):1471-1472.

97. Mercadante S, Fulfaro F. World Health Organization guidelines for cancer pain: a reappraisal. Ann Oncol. 2005;16(supp1 4):iv132-iv135.

98. Coffman BL, King CD, Rios GR, Tephly TR. The glucuronidation of opioids, other xenobiotics, and androgens by human UGT2B7Y(268) and UGT2B7H(268). Drug Metab Dispos. 1998;26(1):73-77. 
99. Smith MT. Neuroexcitatory effects of morphine and hydromorphone: evidence implicating the 3-glucuronide metabolites. Clin Exp Pharmacol Physiol. 2000;27(7):524-528.

100. Coller JK, Christrup LL, Somogyi AA. Role of active metabolites in the use of opioids. Eur J Clin Pharmacol. 2009;65(2):121-139.

101. Pergolizzi JV Jr, Labhsetwar SA, Puenpatom RA, Joo S, Ben-Joseph RH, Summers KH. Prevalence of exposure to potential CYP450 pharmacokinetic drug-drug interactions among patients with chronic low back pain taking opioids. Pain Pract. 2011;11(3):230-239.

102. Gore M, Sadosky A, Leslie D, Sheehan AH. Selecting an appropriate medication for treating neuropathic pain in patients with diabetes: a study using the UK and Germany Mediplus databases. Pain Pract. 2008;8(4):253-262.

103. Duragesic ${ }^{\circledR}$ (fentanyl transdermal system) [prescribing information] Titusville, NJ: Janssen Pharmaceuticals, Inc.; 2012.

104. Saarto T, Wiffen PJ. Antidepressants for neuropathic pain. Cochrane Database Syst Rev. 2007;(4):CD005454.

105. Webster L. Efficacy and safety of dual-opioid therapy in acute pain. Pain Med. 2012;13(suppl 1):S12-S20.

106. NUCYNTA ${ }^{\circledR}$ (tapentadol) [prescribing information]. Titusville, NJ: Janssen Pharmaceuticals Inc.; 2012.

107. Laugsand EA, Jakobsen G, Kaasa S, Klepstad P. Inadequate symptom control in advanced cancer patients across Europe. Support Care Cancer. 2011;19(12):2005-2014

108. Vorsanger G, Xiang J, Bionidi D, et al. Post hoc analyses of data from a 90-day clinical trial evaluating the tolerability and efficacy of tapentadol immediate release and oxycodone immediate release for the relief of moderate to severe pain in elderly and nonelderly patients. Pain Res Manag. 2011;16(4):245-251.

109. Thorpe DM. Management of opioid-induced constipation. Curr Pain Headache Rep. 2001;5(3):237-240.

110. Holzer P, Ahmedzai SH, Niederle N, et al. Opioid-induced bowel dysfunction in cancer-related pain: causes, consequences, and a novel approach for its management. J Opioid Manag. 2009;5(3):145-151.

111. Allan L, Richarz U, Simpson K, Slappendel R. Transdermal fentany versus sustained release oral morphine in strong-opioid naive patients with chronic low back pain. Spine (Phila Pa 1976). 2005;30(22): 2484-2490

112. van Seventer R, Smit JM, Schipper RM, Wicks MA, Zuurmond WW. Comparison of TTS-fentanyl with sustained-release oral morphine in the treatment of patients not using opioids for mild-to-moderate pain. Curr Med Res Opin. 2003;19(6):457-469.

113. Wild JE, Grond S, Kuperwasser B, et al. Long-term safety and tolerability of tapentadol extended release for the management of chronic low back pain or osteoarthritis pain. Pain Pract. 2010;10(5):416-427.

114. Lange B, Kuperwasser B, Okamoto A, et al. Efficacy and safety of tapentadol prolonged release for chronic osteoarthritis pain and low back pain. Adv Ther. 2010;27(6):381-399.

115. Shaheen PE, Walsh D, Lasheen W, Davis MP, Lagman RL. Opioid equianalgesic tables: are they all equally dangerous? J Pain Symptom Manage. 2009;38(3):409-417.

116. The Sidney Kimmel Comprehensive Cancer Center At Johns Hopkins. The Hopkins Opioid Program. Baltimore, MD: Johns Hopkins; 2012 Available from: http://www.hopweb.org/index.cfm?cfid=4634198\&cf token=46515837. Accessed August 7, 2012.

117. McAuley D. GlobalRPh. Detroit, MI: GlobalRPh; 2013. Available from: http://www.globalrph.com/narcoticonv.htm. Accessed June 7, 2013.

118. Practical Pain Management. Online opioid calculator. Montclair, NJ: Vertical Health Media; 2013, LLC. Available from: http://opioidcalculator.practicalpainmanagement.com/. Accessed June 6, 2013.

119. Pereira J, Lawlor P, Vigano A, Dorgan M, Bruera E. Equianalgesic dose ratios for opioids. A critical review and proposals for long-term dosing. J Pain Symptom Manage. 2001;22(2):672-687.

120. Gourlay DL, Heit HA. Universal precautions revisited: managing the inherited pain patient. Pain Med. 2009;10(suppl 2):S115-S123.
121. Poulsen L, Arendt-Nielsen L, Brosen K, Sindrup SH. The hypoalgesic effect of tramadol in relation to CYP2D6. Clin Pharmacol Ther. 1996;60(6):636-644.

122. Fujita K, Ando Y, Yamamoto W, et al. Association of UGT2B7 and ABCB1 genotypes with morphine-induced adverse drug reactions in Japanese patients with cancer. Cancer Chemother Pharmacol. 2010;65(2):251-258

123. Levran O, O'Hara K, Peles E, et al. ABCB1 (MDR1) genetic variants are associated with methadone doses required for effective treatment of heroin dependence. Hum Mol Genet. 2008;17(14):2219-2227.

124. Lotsch J, Zimmermann M, Darimont J, et al. Does the A118G polymorphism at the mu-opioid receptor gene protect against morphine6-glucuronide toxicity? Anesthesiology. 2002;97(4):814-819.

125. Klepstad P, Fladvad T, Skorpen F, et al; European Palliative Care Research Collaborative (EPCRC); European Association for Palliative Care Research Network. Influence from genetic variability on opioid use for cancer pain: a European genetic association study of 2294 cancer pain patients. Pain. 2011;152(5):1139-1145

126. Ferrini F, Trang T, Mattioli TA, et al. Morphine hyperalgesia gated through microglia-mediated disruption of neuronal $\mathrm{Cl}^{-}$homeostasis. Nat Neurosci. 2013;16(2):183-192.

127. Slatkin NE. Opioid switching and rotation in primary care: implementation and clinical utility. Curr Med Res Opin. 2009;25(9): 2133-2150.

128. Hallett BR, Chalkiadis GA. Suspected opioid-induced hyperalgesia in an infant. Br J Anaesth. 2012;108(1):116-118.

129. Sato M, Miyamori T, Koyanagi J, et al. [2 cases of successful symptom management at home by using opioid rotation from a fentanyl preparation to a continuous subcutaneous injection of morphine hydrochloride, at a dose less than the equivalent dose based on the conversion table]. Gan To Kagaku Ryoho. 2012;39(suppl 1):58-60. Japanese.

130. Webster LR, Fine PG. Overdose deaths demand a new paradigm for opioid rotation. Pain Med. 2012;13(4):571-574.

131. Weiner M, Sarantopoulos C, Gordon E. Transdermal buprenorphine controls central neuropathic pain. J Opioid Manag. 2012;8(6): 414-415.

132. Peppin JF. The use of methadone "as needed", is it justified? J Opioid Manag. 2009;5(1):7-9.

133. Matsuyama K, Satomi E, Ueno H, et al. [A case of unresectable advanced pancreatic cancer treated by gemcitabine-based chemotherapy following cancer pain alleviation by low-dose matrix-type transdermal fentanyl]. Gan To Kagaku Ryoho. 2009;36(8):1351-1353. Japanese.

134. Likar R, Krainer B, Sittl R. Challenging the equipotency calculation for transdermal buprenorphine: four case studies. Int J Clin Pract. 2008;62(1):152-156.

135. Okon TR, George ML. Fentanyl-induced neurotoxicity and paradoxic pain. J Pain Symptom Manage. 2008;35(3):327-333.

136. Vorobeychik Y, Chen L, Bush MC, Mao J. Improved opioid analgesic effect following opioid dose reduction. Pain Med. 2008;9(6): 724-727.

137. Akiyama Y, Iseki M, Izawa R, et al. [Usefulness of fentanyl patch (Durotep) in cancer patients when rotated from morphine preparations]. Masui. 2007;56(3):317-323. Japanese.

138. Moryl N, Kogan M, Comfort C, Obbens E. Methadone in the treatment of pain and terminal delirum in advanced cancer patients. Palliat Support Care. 2005;3(4):311-317.

139. Muller-Busch HC, Lindena G, Tietze K, Woskanjan S. Opioid switch in palliative care, opioid choice by clinical need and opioid availability. Eur J Pain. 2005;9(5):571-579.

140. Shinjo T, Okada M. [The opioid combination of transdermal fentanyl and sustained release morphine for refractory cancer pain - a case report]. Gan To Kagaku Ryoho. 2005;32(12):1997-2000. Japanese.

141. Zimmermann C, Seccareccia D, Booth CM, Cottrell W. Rotation to methadone after opioid dose escalation: how should individualization of dosing occur? J Pain Palliat Care Pharmacother. 2005;19(2): $25-31$. 
142. Schriek P. Treatment of cancer-related pain with transdermal buprenorphine: a report of three cases. Support Care Cancer. 2004;12(12):882-884.

143. Daeninck PJ, Bruera E. Reduction in constipation and laxative requirements following opioid rotation to methadone: a report of four cases. J Pain Symptom Manage. 1999;18(4):303-309.

144. Bruera E, Pereira J, Watanabe S, Belzile M, Kuehn N, Hanson J. Opioid rotation in patients with cancer pain. A retrospective comparison of dose ratios between methadone, hydromorphone, and morphine. Cancer. 1996;78(4):852-857.
145. Vigano A, Fan D, Bruera E. Individualized use of methadone and opioid rotation in the comprehensive management of cancer pain associated with poor prognostic indicators. Pain. 1996;67(1):115-119.

146. McCance-Katz EF, Sullivan LE, Nallani S. Drug interactions of clinical importance among the opioids, methadone and buprenorphine, and other frequently prescribed medications: a review. Am J Addict. 2010;19(1):4-16.

147. Overholser BR, Foster DR. Opioid pharmacokinetic drug-drug interactions. Am J Manag Care. 2011;17(suppl 11):S276-S287.

\section{Publish your work in this journal}

The Journal of Pain Research is an international, peer-reviewed, open access, online journal that welcomes laboratory and clinical findings in the fields of pain research and the prevention and management of pain. Original research, reviews, symposium reports, hypothesis formation and commentaries are all considered for publication.

\section{Dovepress}

The manuscript management system is completely online and includes a very quick and fair peer-review system, which is all easy to use. Visit http://www.dovepress.com/testimonials.php to read real quotes from published authors. 